\title{
Toward Modelling a Global Social Contract: Jean-Jacques Rousseau and John Locke
}

\author{
TAKASHI INOGUCHI \\ University of Niigata Prefecture \\ inoguchi@ioc.u-tokyo.ac.jp \\ LIEN THI QUYNH LE \\ University of Hue \\ Itqlien@hce.edu.vn
}

\begin{abstract}
The paper attempts to construct a global model of a social contract using wellknown metaphors of two great philosophers: Jean-Jacques Rousseau and John Locke. By modelling a global social contract, I mean the formulation of a social contract using two sets of data: one is global citizens' preferences about values and norms while the other is sovereign states' participation in multilateral treaties. Both Rousseau and Locke formulate their versions of social contract theories in the national context of eighteenth-century Europe. This paper tries my hands on extending their theories to the global context. This paper attempts to link empirically the relationship between global citizens' preferences as gauged by the World Values Survey and sovereign states' participation in 120 multilateral treaties deposited to the United Nations. To see the link between citizens and treaties (quasi-legislative outcomes, sort of), dimensional similarities of the cosmos of citizens' preference and the cosmos of sovereign states' willingness to join multilateral treaties are examined. Once done, all the sovereign states are located in each of the two cosmoses, citizens and states, and the correlation coefficients between them are measured. Based on these empirical results, the nature of the global quasi-legislative process is clarified. Conclusions and implications are drawn.
\end{abstract}

\section{Introduction}

Global politics has quasi-legislative processes like national legislative processes (Volgy, 1973; Popovski and Fraser, 2014). The differences are: (1) There is no institutionalized world government; hence, there are no claims of sovereign power in global politics. (2) There is no formal institutional legislative body like a national parliament that aggregates citizens' preferences into government policy. However, 
there are mechanisms whereby citizens' preferences are selectively chosen to generate multilateral treaties in which sovereign states join or do not join.

In a national parliamentary democratic setting, the legislative branch takes care of legislation while the executive branch takes care of policy implementation. The members of the legislative branch are elected by citizens or electors. How electors' preferences are reflected and materialized in legislated bills is called the branch of legislative politics. Otto Bismarck once remarked that legislation is like making sausages into the process of which every conceivable source is fed.

In the real world, there is no global legislative mechanism with legislative and executive branches. There is no legal mechanism whereby global citizens' preferences are fed into laws, which in turn function as a set of global public policies. Yet if one envisages that those public opinions expressed and revealed to the public and those multilateral treaties and conventions signed, ratified, and further implemented are equivalent to nationally surveyed citizens' preferences and nationally legislated bills respectively, there emerges global quasi-legislative politics.

On what may be called the global quasi-legislative process and its outcome, there have been plentiful of studies examining how global climate policy initiatives have been attempted at Tokyo, Copenhagen, and Paris (Kutney, 2013; Sovacool and Dworkin, 2014, Brainard et al. 2009); analyzing how a global trade liberalization scheme has been agreed but only with the scope less than global and comprehensive, i.e., bilateral, regional, and partial (Jones, 2015); examining how the nuclear non-proliferation treaty has experienced the diffusion of new nuclear powers (Joyner, 2013; Solingen, 2012); and tracing how a multilateral agreement on fire-control radar was crafted during the meeting of the navies of some 22 countries that assembled in Shandong, China amidst the Japan-China disputes in the East China Sea in 2013 (Inoguchi, 2015).

Despite the ever-increasing multilateral agreements, conventions, and treaties of all kinds, a comprehensive picture has not been provided in any systematic and statistical format (Kajima Institute of Peace, 2015). Although some global pictures of citizens' preferences and perceptions have been analyzed by Ronald Inglehart (1997), Pippa Norris (2004), Christian Welzel (2013), and Miguel Basanez (2015), the task of empirically and statistically analyzing the links between citizens' preferences and states joining multilateral treaties has never been carried out. This task is what this article sets out to do.

When the quasi-legislation process and outcome is focused on one policy area, this genre of academic research is often called regime theory (Krasner, 1983; Yamamoto, 2008). There are many regimes such as the nuclear non-proliferation regime, climate change regime, free trade regime, intellectual property regime, public health regime, human rights regime. Regime research has done a lot to describe and define multilateral agreements, conventions, and treaties on some specialized subjects. Regime research gives pictures of global quasi-legislative processes when they are digested as a whole in terms of quasi-legislative impulses, interactions, and impacts. Yet so far no research has been conducted on this genre of research to see how these three key knots in the 
global quasi-legislative processes are related in numerical terms. One exception exists however: nuclear non-proliferation regime analysis (Brenner, 1981[2009]) has been undertaken to shed new light on the quasi-legislative processes in terms of impulses, interactions, and impacts in statistical terms. Among the most important findings is the positive correlation between technologically advanced countries' assistance to less technologically advanced countries in the area of nuclear power generation for peaceful purposes and nuclear proliferation. This is one strong step forward in making regime analysis more holistic, not just in one regime.

The framework we propose to use for analysing global quasi-legislative processes is to posit a model using the metaphors of Rousseau and Locke. The Rousseauesque metaphor focuses on citizens' preferences and sovereign states' participation in multilateral treaties, setting aside intermediaries of quasi-legislature bodies. Rousseau's Social Contract does not envisage any legislative bodies even in national settings. That is why Rousseau is sometimes regarded as proposing direct democracy. In the city republic of Geneva, such an envisioning has a semblance of direct democracy. Yet the point is that Rousseau was a philosopher of the primacy of reason, human intellectual power around the time of the French Revolution. Such philosophers as Condorcet, Diderot, Borda all believed in the primacy of human brains at the time when God's power was regarded as declining.

Azuma (2011) has proposed in his General Will 2.o that Rousseau's idea of aggregating citizens' preferences can be theorized as Google mapping via Sigmund Freud. Sigmund Freud discovered unconsciousness and it is Azuma's (2011) interpretation that Rousseau's Social Contract contains the untalked-about role of the unconsciousness, and that with no intermediate bodies such as legislative institutions Rousseau's model is complete. When is operationalized, Rousseau's General Will (volonte generale) becomes General Will 2.o. It is similar to Cass Sunstein's (2001) Republic.com. 2.o.

Operationally speaking, citizens' preferences are linked with states' participation in multilateral treaties to enable us to factor analyse citizens' preferences and states' participation in multilateral treaties separately to see whether their dimensionalities are more or less of the same kind. To carry out this analysis, the correlation coefficients between those factor scores of states of citizens' preferences and those scores of states' participation in multilateral treaties are useful to see the similarity of the dimensionalities. Also the states' locations on those dimensions, derived from two factor analyses, will be used to enhance similar dimensionalities. If these operations are carried out successfully, then the Rousseauesque metaphor is to be grosso modo useful.

The Locke metaphor consists of three knots: (1) citizens' preferences, (2) quasilegislative bodies, and (3) states' participation in multilateral treaties. A new element is 2) quasi-legislative bodies. How should we define this element? As regime research has amply shown, a bundle of intermediaries exists in global quasi-legislative processes: some 200 sovereign states and members of the United Nations, tens of thousands of non-governmental organizations, UN specialized institutions, non-UN affiliated 
international and transnational organizations, non-governmental individuals etc. How should we generate numerical indicators of quasi-legislative bodies?

We must recall what Rousseau and Locke used as metaphors. They were immensely constrained by the historical background of the eighteenth-century Europe. Rousseau had no map of the world let alone a global social contract. Rousseau thought about Poland and Corsica - Poland because it symbolized terrible aristocratic feudalism; Corsica because it symbolized an uncivilized space. In both, something could be done to elevate the level of political and moral life, according to Rousseau (Sarkar Muthu, 2015: 270-306).

Besides the difficulty in imagining globalization itself in the twenty-first century, Rousseau's philosophical articulation focuses on the general will rather than a social contract; in this way, he inspires and allures readers by the power of his writing. Therefore, Judith Shklar (1969) famously notes, 'The general will is Rousseau's most successful metaphor. It conveyed everything he wanted to say.' Troublesome, according to Farr and Williams (2015), is 'what he most wanted to say was not entirely new or unprecedented. Neither was it perfectly clear or invariably well received. But the concept of the general will did succeed in becoming central to the contentious imagination of modernity after ... and largely because of Rousseau.' In Judith Shklar's (1973) words, 'The phrase "general will" is ineluctably the property of one man, Jean-Jacques Rousseau.' 'No, he did not invent it. But he made its history.' Hence, a large space remains for the articulation, and the operationalization, of the general will, or the particular will, in its secular life form.

Furthermore, Rousseau had two philosophers, Immanuel Kant and Sigmund Freud, who tackled Rousseau's ideas head on. However, their solutions are not easily amenable to operationalization either. Impressed by Rousseau's ideas, Kant eventually came up with the concept of the categorical imperative, which can be defined as a way of evaluating motivations for action; for example, 'So act that your principle of action might safely be made a law for the whole world.' Instead of Rousseau's general will of the citizen, Kant focused on the good will of the individual (Riley, 2015: 333-49). To link the good will of the individual with the general will of the citizen, a philosophical bridge between them must be considered.

Freud moved in a different direction far from the rationalism at the time of French Revolution. In human beings, the unconsciousness mind impacts on behaviour. So even though the individual is aware of what is going on in the conscious mind, the unconscious mind can still control thought processes. Freud was a precursor of neuroscience in the late twentieth and early twenty-first centuries by insisting on the significant part played by the unconscious mind. Neuroscience played an important role in Rousseau's thinking.

Locke lived in England in the eighteenth century, which was so provincial and peripheral that the Vatican's influence was restrained, and the king's authority and power was receding steadily. Locke focused on the gradual expansion of parliamentary power and the politics therein, i.e. the growth of a representative democracy. Locke 
was lucky in that his concept of representative democracy was broad and yet clear in its meaning. Riding high on the then early Industrial Revolution and the rise of the West, the concept flourished and diffused worldwide. Locke is often thought of as the father of liberalism not merely a contributor to the development of English constitutional thought, or as a reflector of socio-economic change in seventeenth-century England (Dunn, 1994). Nevertheless, the world of globalization in the twenty-first century was not imagined by Locke or his disciples. As Keane (2009) has demonstrated eloquently in his magnum opus, democracy is not a monopoly of the West. Representative democracy in variant forms and names abound in history. Between global citizens and global quasi-legislation lie a huge number of legislative interveners of many kinds. Unlike the English parliament of Locke's time, there is no formal global assembly or no formal legislators. Distinction between legislators and non-legislators worldwide is not easy to make. Hence some conceptual difficulties to introduce the representative democratic model of Locke writ large on a global scale.

What must be stressed is that the Rousseauesque and Lockean metaphors remain metaphors and that our model, which is inspired by their philosophical thrusts, is not necessarily strict in distinguishing between Rousseau and Locke for two reasons: first, because they did not imagine the world of globalization and digitalization; second, because neither of them articulated or specified how their models of direct or representative democracy could possibly function in a steadily globalizing world.

\section{Different backgrounds of the Rousseauesque and Lockian metaphors of social contract}

It is no coincidence that Rousseau and Locke lived their philosophical lives in the seventeenth-eighteenth century Switzerland and England, respectively. These two countries, along with Sweden, are, according to Laurence Whitehead (2002), the earliest modern origins of democracy in Europe. Whitehead argues that three conditions were ripe in these countries. First, they were peripheral countries in Europe; second, they were the least influence by the Vatican; third, their societies were parochial and primitive. Switzerland consisted of cantons in which people knew each other so intimately that 'the notion of representation' was alien to their direct democracy where every citizen was a legislator (Cranston, 1985: 20). England consisted of slowly emerging self-assertive parliamentarians and the increasingly non-despotic King. They set up its own national Anglican church by severing ties with the Vatican. Therefore it is no wonder that Switzerland and England developed their respective versions of democracy: direct democracy in Switzerland (Barber, 1974, 2004) and representative democracy in England (Dunn, 1994).

The setting of the Rousseauesque metaphor is Switzerland in the eighteenth century. When every citizen was a legislator, aggrandizing a legislative body was not an issue - hence, direct democracy. To extend direct democracy without a legislative body into global direct democracy means that global citizens express themselves and the accumulation of their expressions are bound to become social contract. 
Rousseau does not articulate the 'legislative process' since it is of no use. Instead of a legislative body, Rousseau sometimes refers to the reason of human beings which was about to replace God in formulating a society in Europe, especially in France where philosophers, including Didorot, Borda, D’Alembert, Montesquieu, Voltaire, and, of course, Rousseau, stressed the primacy of human reasoning in running a society. A strong argument can be made when envisaging global politics as being Rousseauesque is that without a formal legislative body, and indeed without a global polity, multilateral treaties would become overwhelming and global citizens' preferences would appear on the internet in an endless stream as well as through more conventional media. The advent of the internet, and other social networking services, has led global politics to the incessant bursting of expressions in all directions.

\section{Key driver of Rousseauesque metaphor: the post-modern rise of the internet}

The Rousseauesque metaphor has been able to grow globally due in large part to the rise of the Internet and social networking services. The Internet allows us to share emotions with others (Turkle, 2012), which results in what Sunstein (2001) calls cyberbalkanization of society. The dramatic rise in individuals' self-expression of sentiments and opinions has made society vis-à-vis the power of the state formidable. Before, the state almost monopolized power. Now not only citizens are monitored by the state but also the state is monitored by citizens. John Keane (2009) calls this monitory democracy. And no less importantly, the relationship has become transnational. Thanks to technological progress, direct democracy, which used to be applicable only on a small scale, has become global. One of the important differences between Rousseau and Locke is that the solid construct in Rousseau is between the state and each citizen, whereas the solid construct in Locke is among citizens themselves. In other words, Rousseau's construct is between the state and sovereignty as the aggregation of the citizens (Suzuki, 2013).

\section{Key driver of the Lockean metaphor: the post-modern rise of transnational organizations and movements}

The setting of the Lockean metaphor is England in the seventeenth-eighteenth centuries. By the late seventeenth century, the absolutism of the King was settled (the Glorious Revolution of 1688) and the stability of politics was somehow assured by the Declaration of Rights. Since then, English politics has evolved surrounding the competition of parliamentarians in legislating laws, and politics became law making. Legislation and representation have become key to English politics. John Locke became a god of representative democratic politics. Extending the Lockean metaphor into global politics poses a difficulty in handling what is a legislative body. When global politics is often regarded as politics of power in the Hobbesian mold, how can we envisage global politics as Lockean? In a sense, global politics focuses on legislation based on multilateral treaties as well as bilateral agreements. A glance at the number of war-related deaths reveals the dramatic decline in treaties over the last 77 years: 5 million 
per year during 1938-1945; 100 thousands per year during 1945-89; and 10 thousands per year during 1989-2015. The number of multilateral treaties has increased by leaps and bounds (Inoguchi, 2015; Le et al., 2014):

The Lockean model has been transformed into a global model due in large part to the rise of transnational organizations and movements (Hale and Held, 2011). Transnational organizations have risen in terms of size, budget, and capacity to tackle global, regional, and national issues with recruitment by meritocratic and professional criteria. It was in 1973 that Samuel Huntington (1978) called their pronounced rise a transnational organizational revolution in world politics. When national governments cannot cope with such global issues as climate change, terrorism, cyber attacks, free trade, development, human rights, disarmament with national governments alone, transnational organizations stand up to carry out varieties of tasks (Drezner, 2014). It is recognition by almost powerless national governments regarding the relentless climate change, which is transforming the earth and affecting human lives with exceedingly hot temperature, massive rainfalls, monstrously strong winds, that led to as many as 160 countries to promulgate the Paris convention on climate change in 2015. No less important to note is the rise of transnational movements that contend and compete as well as augment and assist transnational organizations with their oft-times deeper penetration into local social forces. McAdam and Tarrow (2001) argued in 'Sale Shift in Transnational Contention' that internationalization and globalization have promoted the expansion of social protest, international relations, and social movements.

\section{Concept and measurement of global citizens' preferences}

Since George Gallup set up the American Institute of Public Opinion in New York in 1935, numerous opinion polls have been carried out. Not one week passes nowadays without seeing new polling results in daily newspapers. In business, politics, and mass media, opinion polls have become indispensable instruments to view the direction of human thinking and actions in the future. Yet one thing has not changed at all since 1935, despite all the tides of globalization for eight decades. All the opinion polls are nationally sampled, whether randomly sampled or not. There has never been a randomly sampled global poll conducted. There is neither a theory of global sampling nor an underlying theory of global citizens in a global polity. So what we have is an assemblage of nationally sampled respondents' answers, often across nations.

Ideally, since our task is to see global citizens' preferences on values and norms, the theory of global sampling should underpin the task of sampling. The fact is that the World Values Survey, most frequently cited and used survey in this domain of polls, uses an assemblage of nationally sampled polls from over 150 countries. Gilani and Inoguchi (2013) articulate the theory of global sampling. The population is in this theory an entire global population of, say, 7 billion persons. Global sampling is conducted in terms of many blocs, each of which contains, say, one million persons. Google Earth is utilized to measure such blocs. Instead of an assemblage of nationally sampled persons, globally sampled respondents are drawn from many-units. Once a globally sampled 
survey is carried out, data analysis is straightforward and does not require having a number of respondents weighted according to each national population. Data analysis is globally carried out based on the characteristics of, say, lifestyles of the middle-income class, religiosity of Christians or Muslims or Buddhists. Yet the World Values Survey is based not on the theory of global sampling but on the theory of national sampling. Therefore, it is an assemblage of cross-national surveys conducted every ten to five years throughout the world. This is the best available until the globally sampled survey is validated to yield no less scientific and more cost-efficient results. Some simulation results are encourage us to further pursue this logic.

\section{Concept and measurement of multilateral treaties (Le et al., 2014)}

No sampling is necessary in collecting multilateral treaties. Most of them are registered in the United Nations. They also contain some of those registered in the League of Nations (1918-38) and some of them even before 1918. The global legislative outputs are based on its entirety, except for those that do not fit as a multilateral treaty. One hundred and twenty treaties are examined. The earliest and latest multilateral treaties in each of the six policy domains are listed in Appendix 1. Each treaty is described using the following attributes:

- Policy domain: Treaties are categorized into six areas: human rights, peace and security, environment, intellectual property rights, commerce and communication, and labor

- The year that a treaty was registered with the relevant international body

- The type of increase of those states that join multilateral treaties concerned: Four types of membership are proposed and the respective graph is drawn for each treaty, namely: A. Unipolar (the treaties that do not enjoy many members); B. Steady increase; C. Popular with a jump in the number of members at a certain point; D. Popular with very many members from the start.

- The name of the ten geo-historico-cultural groups by Christian Welzel (2013) in a modified form: (1) Indic East, (2) Islamic East, (3) Latin America, (4) New West, (5) Old West, (6) Orthodox East, (7) Reformed West, (8) Sinic East, (9) Sub-Saharan Africa, (10) Returned West (see Appendix 2 for the Welzel list and the modified Le/Inoguchi list).

- The number of current members as of 2014

\section{Gauging links between citizens' preferences and states' treaty participation}

We have so far concentrated on describing our procedure of linking global citizens' preferences and states' participation in multilateral treaties. The question we should tackle before gauging such links is: Should we assume the scheme of a global quasilegislative process in a global political system, where there are no sovereign institutions, with democratically elected representatives and professionally chosen bureaucrats who 
together construct agreements and execute laws facing seven billion citizens without borders? Our answer is no. Our first task - the most important task - is to describe citizens' preferences in terms of collectively unconscious desires and passions. Since the World Values Survey keeps asking about values and norms, in other words about what citizens aspire to and want to materialize, we have to highlight via statistical methods the fairly strong collective desires. Since the Multilateral Treaties Survey keeps registering the common ground between states' in treaties and conventions, for our second task we have to highlight via statistical methods that the fairly strong collective passions are part of such multilateral treaties and conventions. After these two tasks are carried out, our next task is to assess their links in one way or another.

The kind of statistical procedure that best fitted our task was factor analysis via varimax rotation. Citizens' preferences have been most intensively studied by the World Values Survey team (Inglehart and Welzel, 2005; Welzel, 2013; Basanez, 2015). States' participation in multilateral treaties has been studied by the Multilateral Treaties project team (Le et al., 2014). The former task has been masterfully carried out by Welzel (2013); we summarize his results only to the extent to which they are pertinent to our present task.

Welzel (2013) has factor-analysed the data of the World Values Survey for 201012, with the following dimensions and states' locations. Since the World Values Survey project has been sustained since the mid-1970s, it has undergone five waves of worldwide surveys on values and norms. Welzel (2013) utilizes data from the latest wave that covers 93 countries and includes from each region in the world those countries with biggest populations and largest economies. Thus, the data represent almost 90\% of the world's population. The key two dimensions that have emerged from his analysis are similar to the previous World Values Survey studies but differ in the labeling of the dimensions reflecting changing citizens' values and norms and in the author's different focus in framing analysis.

The first dimension is Emancipative versus Protective and the second dimension is Secular versus Sacred. Emancipative means that citizens want freedom and openness, whereas Protective means that citizens want regulation, care, and protection. Secular means that citizens want non-religious life, whereas Sacred means that citizens want religious life. Since the whole questionnaire is tailored to values and norms and related subjects, this is most indicative of what citizens aspire to and want to materialize.

Welzel places the above shown ten geo-historico-cultural country groups onto these two dimensions. Welzel's grouping focuses on the West and therefore the differences among the West is sharply delineated, whereas the non-West is less so. Nevertheless, most striking is the predominance of the West. In the rough order of high scores on the emancipative versus protective dimension:

Reformed West, meaning those countries that were reshaped after the Reformation, are most emancipative. They include Germany, Netherlands, Sweden, Switzerland, Norway, and Finland. 
Old West, meaning those countries that were established after the Roman Empire, are next most emancipative. They include France, Italy, and Spain.

New West, meaning those countries in the Americas that were born in the New American Continent and the Pacific. They include the United States, Canada, New Zealand, and Australia.

Latin America, meaning those countries that were shaped after the French Revolution. They include Mexico, Venezuela, Brazil, Cuba, and Argentine.

Returned West, meaning those countries that returned to the West after the Cold War. They include the Czech Republic, Slovenia, Croatia, Estonia, and Lithuania.

Sub-Saharan Africa, meaning Africa below the Sahara. They include Nigeria, Liberia, Ghana, Benin, Mozambique, and Democratic Republic of Congo.

Orthodox East, meaning those countries whose key religious denomination is Russian orthodox. They include Russia, Georgia, Serbia, and Montenegro.

Sinic East, meaning those countries heavily affected by the Chinese civilization. They include China, Japan, South Korea, and Vietnam.

Indic East, meaning those countries heavily influenced by the Indian civilization. They include India, Pakistan, Bangladesh, Sri Lanka, Nepal, and Bhutan.

Islamic East, meaning those countries heavily influenced by Islamic religion in the Middle East and North Africa. They include Egypt, Turkey, Morocco, Algeria, Lebanon, Jordan, Kuwait, Saudi Arabia, and United Arab Emirates.

Similarly, on the Secular versus Sacred dimension, in rough order of Secular versus Sacred, it is as follows:

\author{
Sinic East \\ Reformed West \\ Returned West \\ Orthodox East \\ Old West \\ New West \\ Indic West \\ Islamic West \\ Latin America \\ Sub-Saharan Africa
}

Most striking is that the most secular position is occupied by the Sinic East. It is known for the origin of meritocracy, i.e., some 2000 years back in Qin China's Emperor Shi as contrasted to some 200 and odd years back in England. Next most secular is 
Table 1. Six variables of the factor analysis on multilateral treaties data

\begin{tabular}{|c|c|}
\hline Variable & Description \\
\hline $\begin{array}{l}\text { Year of membership } \\
\text { [YrMember] }\end{array}$ & The year when a country ratified a treaty is identified \\
\hline Year of Deposit [YrDeposit] & $\begin{array}{l}\text { The year when a treaty is deposited to the relevant international } \\
\text { body }\end{array}$ \\
\hline $\begin{array}{l}\text { Number of Current } \\
\text { Members } \\
\text { [CurrentMember] }\end{array}$ & The number of current member countries of a treaty as of 2014 \\
\hline $\begin{array}{l}\text { Global Leadership } \\
\text { Willingness [GLW] }\end{array}$ & $\begin{array}{l}\text { A quantitative index to measure how quickly a country responds } \\
\text { to the formulation of a treaty and is calculated based on the } \\
\text { number of elapsed years between the promulgation of a } \\
\text { treaty and a country's ratification act. }\end{array}$ \\
\hline $\begin{array}{l}\text { Modified Welzel Regional } \\
\text { Group [Region] }\end{array}$ & $\begin{array}{l}\text { A country is classified in one of the ten geo-historico-cultural } \\
\text { groups by Christian Welzel (2013) in its modified form by the } \\
\text { Le/Inoguchi scheme (Appendix 2). }\end{array}$ \\
\hline Policy Domain [Domain] & $\begin{array}{l}\text { The six policy domain categorizations based on the main } \\
\text { purpose of a treaty }\end{array}$ \\
\hline
\end{tabular}

the Reformed West (those countries established after the Reformation). Non-Catholic populations in the Reformed West are placed at this level of secularity. In terms of secularity, the Returned West (post-Cold War Central and Eastern Europe) comes in third. The Orthodox East comes next. Seven decades of communist rule secularized societies very much. Yet the post-communist societies have revived non-secularity significantly. Following the Orthodox East is the Old West (those countries established after the Roman Empire). The Republic of France's culture for laicite leads to the endeavor for secularity in schools and other institutions. The Old West, new settler societies, is the most religious of the West. Especially the United States of America is known for high religiosity. Also the famous hypothesis of Protestantism and the Ethics of Capitalism by Max Weber, the sociologist, is not sustained there. Catholics register higher academic scores than non-Catholic populations. Then come the whole range of non-West countries, albeit not including the Sinic East. Religiosity gets higher in the order for the Indic East, the Islamic East, Latin America, and Sub-Saharan Africa. The Indic East is most religious in Asia but outside Asia it is the least religious.

Next we have factor-analysed states' participation in multilateral treaties. For that purpose, the principal component of analysis with varimax rotation and Kaiser normalization based on six variables that represent six attributes of multilateral treaties is implemented (Table 1).

Table 2 lists the three most important dimensions that emerged using factor analysis of the multilateral treaties data. These dimensions explain nearly $70 \%$ of cumulative variance. The two items Year of Membership and Year of Deposit tap the first component that is named Agile versus Cautious. The second dimension, the so-called Global Commons versus Individual Citizens' Rights, is based on the two items Policy 
Table 2. Factor analysis using principal component analysis with varimax rotation and Kaiser normalization: sovereign states' participation in multilateral treaties

Component

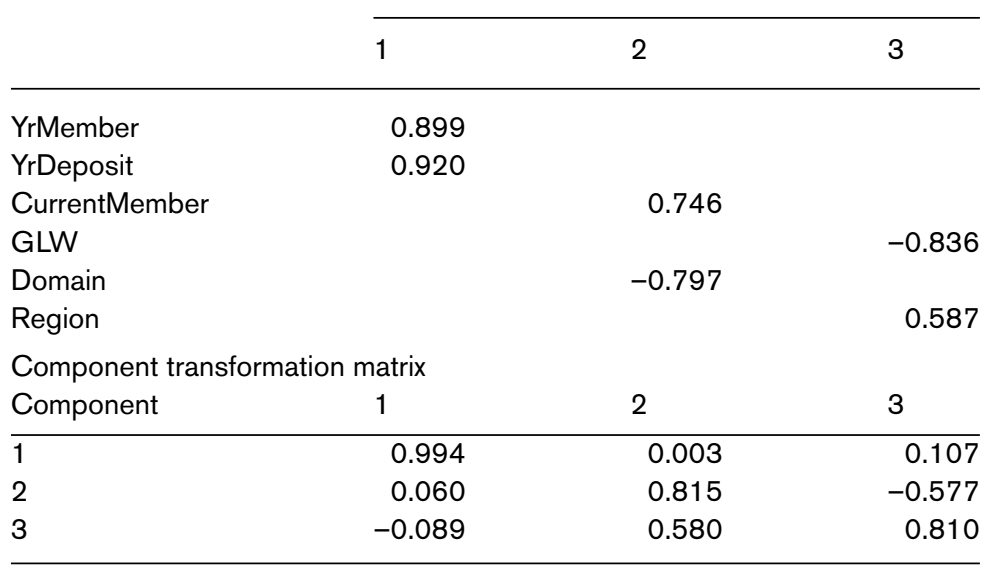

Domain and Number of Current Members. Thirdly, the two items Global Leadership Willingness and Modified Welzel Regional Group form the third dimension that is labeled as Aspirational Bonding versus Mutual Binding.

The first dimension Agile versus Cautious has to do with how nimble or prudent a country is in joining multilateral treaties. Naturally, those countries which became independent immediately after the Second World War and those countries who got independent in the fourth quarter of the last century are cautious: always apprehensive of the possibility of being constrained by such treaties when their precious national independence was obtained. Accumulation of professional expertise and organizational leadership by Western countries have made a huge difference in joining multilateral treaties. In the rough order of high scores on the second dimension:

Reformed West

Old West

Latin America

Sinic East

Islamic East

Indic East

New West

Sub-Saharan Africa

Returned West

Orthodox East 
The second dimension that is labeled as Global Commons versus Individual Citizens' Rights is concerned with whether primary concerns are the environment, peace and security, intellectual property rights on the one hand and labor, occupational health and safety, human rights on the other. In the rough order of those country groups, it is as follows:

Reformed West
Old West
Returned West
Latin America
Sinic East
Orthodox East
New West
Islamic East
Indic East
Sub-Saharan Africa

Most striking is the most global position of the Reformed West. Their concern about global commons is reflected in the generation of highly skilled professionals manning the United Nations and other special international organizations and transnational social movements. The Nobel peace prize, Copenhagen initiative in environmentalism, yearning for Ikeya-style innovation and invention are some of the features of the Reformed West. Then comes the Old West, the Returned West, Latin America, and the Sinic East. They balance the global commons and the individual citizen's rights. Not curiously, the Orthodox East (including Russia) and the New West (including the United States) lean toward individual citizen's rights. It might as well be indicative of the declined counter-hegemony and the declining hegemony that they are assertive of their citizen's rights and interests. The Islamic West, the Indic East and Sub-Saharan Africa reveal their yearning for independence and state sovereignty.

The third dimension is called Aspirational Bonding versus Mutual Binding. Multilateral treaties are often qualitatively different from national laws in terms of the degree of binding. They often contain those appealing to aspirational bonding. High on Aspirational Bonding are Sub-Saharan Africa, Latin America, the Sinic East, the Islamic East, the Indic East, the Orthodox East - all represent Global South's collective voice - registering their yearning rather than being mutually bound. In contrast, the Returned West, the Old West, the New West, and the Reformed West quietly generate rules that bind the rest as much as possible. In the rough order of high/low on the third dimension:

Sub-Saharan Africa

Latin America 
Sinic East

Islamic East

Indic East

Orthodox East

Returned West

New West

Old West

Reformed West

To gauge the link between the Cultural Map of the World (CMW) produced from Welzel's World Values Survey data and the Legislative Map of the World (LMW) obtained from factor-analysed states' partition in multilateral treaties, there is the need to estimate missing data. There are data for 93 countries in the Welzel data set, while there are data for 193 UN member states. To solve this gap of data, we proceed as follows:

1. Identify the region in the Welzel scheme (say, Islamic East) to which a country with missing data belongs. When there is a country that does not show up in the Welzel groups, we judge its belongingness, judging from a country's historical, geographical, and cultural features.

2. Calculate the sum of scores of those countries which belong to the region (say, Islamic East) and whose scores are available.

3. Calculate the mean.

4. Use the mean as an estimated value of missing data.

With this estimation of missing data, the CMW data for all 193 UN member states are calculated and combined with the LMW data. Thus, the correlation coefficients between citizens' preferences and states' participation in multilateral treaties can be calculated.

Table 3 shows all the major dimensions emerged from CMW factor-analysed data (Welzel, 2013) and LMW factor-analysed data, listed along with their abbreviated forms.

To see the similarities between citizens' preferences and the sovereign states' willingness to join multilateral treaties, the correlation coefficients between the CMW and the LMW are shown in Table 4.

We focus on the absolute values of these coefficients, since plus and minus can be converted if protective versus emancipative are phrased as emancipative versus protective, and if sacred versus secular are phrased as secular versus sacred. Then we examine the correlation coefficients between the CMW and the LMW.

First, the correlation coefficient between Pr-Em and Ag-Ca, i.e., 0.324, is fairly high. Agile are mostly countries from the developed north and cautious are mostly those from the developing south. Since the latter half of the twentieth century, liberalization and 
Table 3. CMW factor-analysed data and LMW factor-analysed data, listed with their abbreviated forms

\begin{tabular}{ll}
\hline $\begin{array}{l}\text { The CMW factor-analyzed with varimax } \\
\text { rotation yields two major dimensions }\end{array}$ & 1. Protective versus Emancipative (Pr-Em) \\
$\begin{array}{l}\text { The LMW factor analysed with varimax } \\
\text { rotation yields three major dimensions }\end{array}$ & $\begin{array}{l}\text { 1. Agile versus Cautious (Ag-Ca) } \\
\text { 2. Global Commons versus Individual Citizens' } \\
\text { Rights (Gc-lcr) } \\
\text { 3. Aspirational Bonding versus Mutual Binding } \\
\text { (Ab-Mb) }\end{array}$ \\
\hline
\end{tabular}

Table 4. Correlation coefficients between the CMW and the LMW

\begin{tabular}{lrrrrr} 
& Pr-Em & Sa-Se & Ag-Ca & Gc-Icr & \multicolumn{1}{c}{ Ab-Mb } \\
\hline Pr-Em & 1.000 & 0.156 & -0.324 & -0.433 & 0.495 \\
Sa-Se & 0.156 & 1.000 & -0.066 & -0.325 & 0.619 \\
Ag-Ca & -0.324 & -0.066 & 1.000 & 0.769 & -0.527 \\
Gc-Icr & -0.433 & -0.325 & 0.769 & 1.000 & -0.737 \\
Ab-Mb & 0.495 & 0.619 & -0.527 & -0.737 & 1.000 \\
\hline
\end{tabular}

globalization has increased in the world, so this figure makes eminent sense. The CMW and the LMW correlate fairly well.

Second, the correlation coefficient between Pr-Em and Gc-Icr, i.e., 0.433, is fairly high. The degree to which global commons are easier for the developed north to envisage, while the degree to which individual citizens' rights are more universally acknowledged for the developing south.

Third, the correlation coefficient between Pr-Em and Ab-Mb, i.e., 0.495, is high. The developing south can be protective in its overall attitude - for instance, it can express aspirations to respect gender equality.

Fourth, the correlation coefficient between Sa-Se and Ag-Ca, i.e., o.066, is low. This means that the distinction between Sacred and Secular has little to do with the distinction between Agile versus Cautious. The New West and Sub-Saharan Africa have many commonalities, for instance.

Fifth, the correlation coefficient between Sa-Se and Gc-Icr, i.e., 0.325, is fairly high. The developing south stresses Sacred and Individual citizens' rights.

Sixth, the correlation coefficient between $\mathrm{Sa}-\mathrm{Se}$ and $\mathrm{Ab}-\mathrm{Mb}$, i.e., o.619, is very high. Sacred and Aspirational Bonding have a lot in common.

To sum up, Sa-Se and Ab-Mb are highly correlated each other. Sa-Se and Ag-Ca are the least correlated. The rest exhibit fairly high correlation coefficients. 
Table 5. Correlation coefficients calculated without estimations of the missing data

\begin{tabular}{lrrrrr} 
& Pr-Em & Sa-Se & Ag-Ca & Gc-lcr & \multicolumn{1}{c}{ Ab-Mb } \\
\hline Pr-Em & 1.000 & 0.129 & -0.443 & -0.622 & 0.559 \\
Sa-Se & 0.129 & 1.000 & 0.059 & 0.187 & 0.452 \\
Ag-Ca & -0.443 & 0.059 & 1.000 & 0.795 & -0.558 \\
Gc-lcr & -0.662 & -0.187 & 0.795 & 1.000 & -0.737 \\
Ab-Mb & 0.559 & 0.452 & -0.558 & -0.774 & 1.000 \\
\hline
\end{tabular}

In order to see the robustness of correlation coefficients calculated on the basis of the estimations of the missing data, correlation coefficients calculated without these estimations are shown in Table 5.

Appraisal of the correlation coefficients for CMW and LMW with and without use of estimated data has shown that the results are robust. They are very similar. Use of this estimation is justified.

The ten modified Welzel groups' locations on the CMW and the LMW are as follows.

[Figures 1a, 1b, 2a, 2b, 3a, 3b, 4a, 4b, 5a, 5b, 6a, 6b]

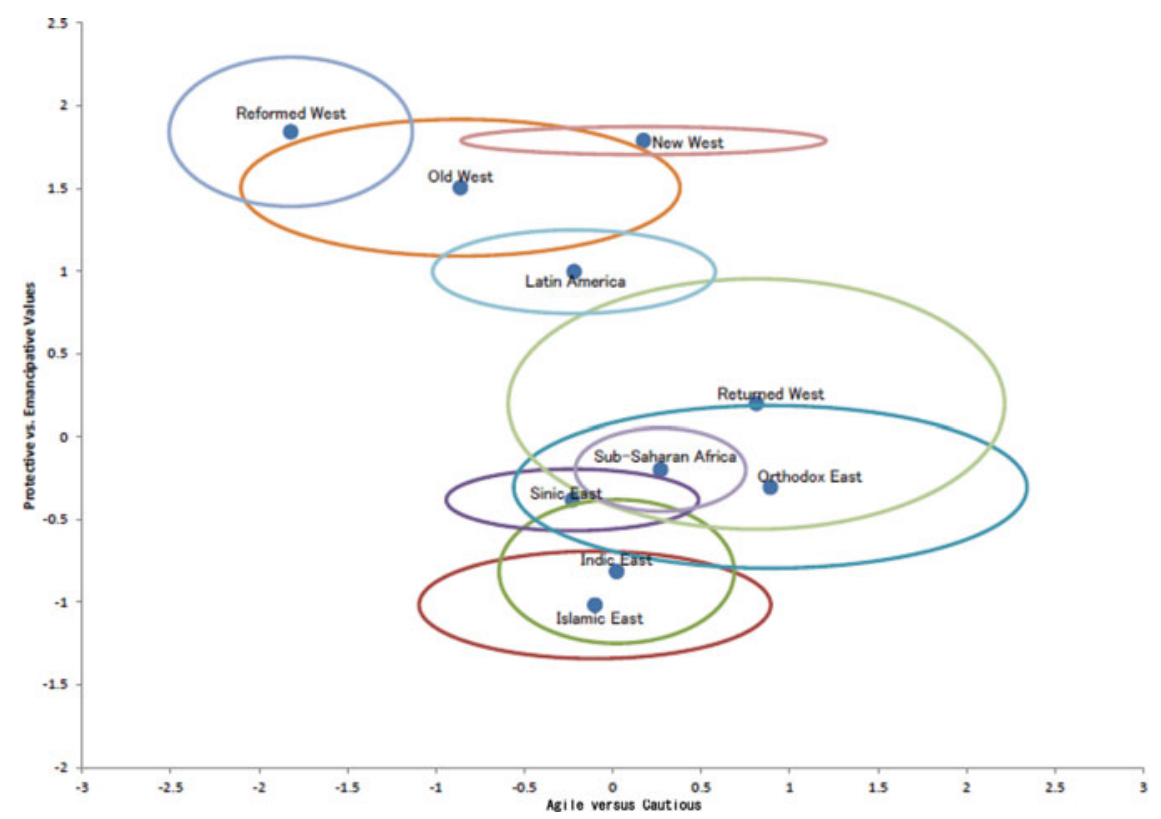

Figure 1a. Ten groups of countries located onto dimensions (Ag-CaxPr-Em) with partially estimated data 


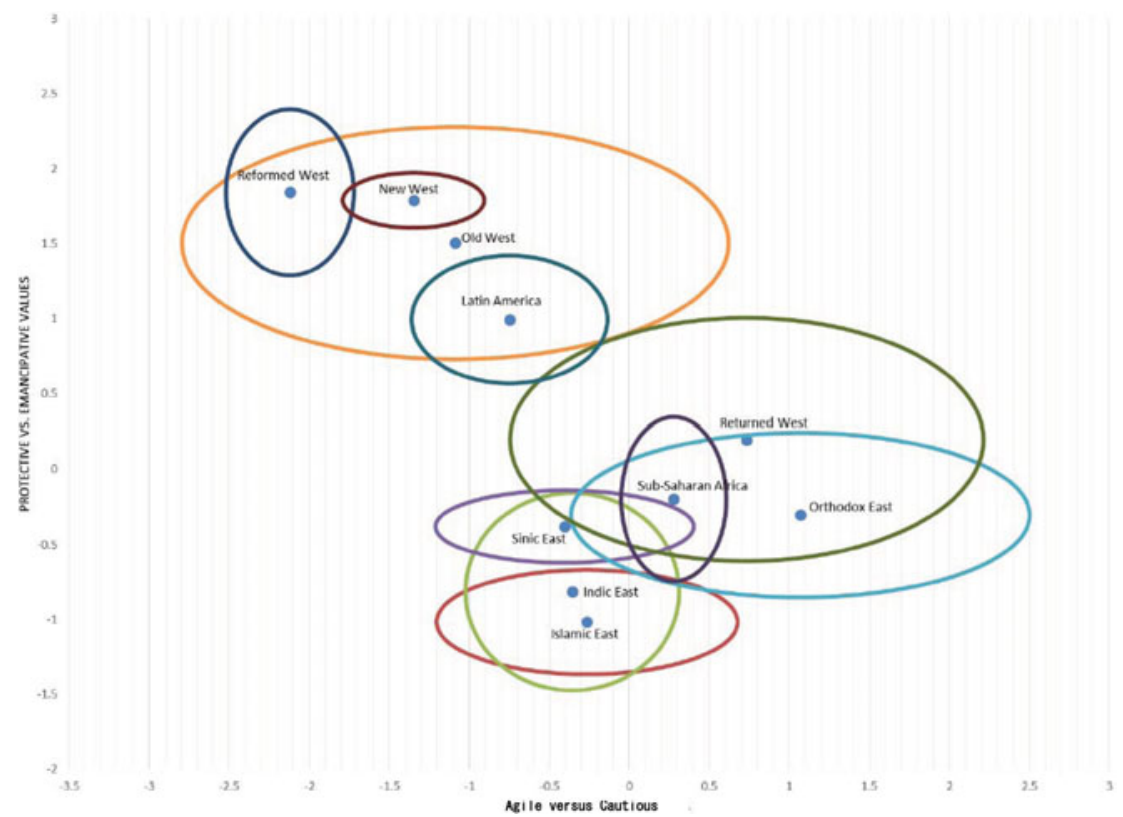

Figure 1b. Ten groups of countries located onto dimensions ( $\mathrm{Ag}-\mathrm{Ca} \times \mathrm{Pr}-\mathrm{Em})$ without estimated data

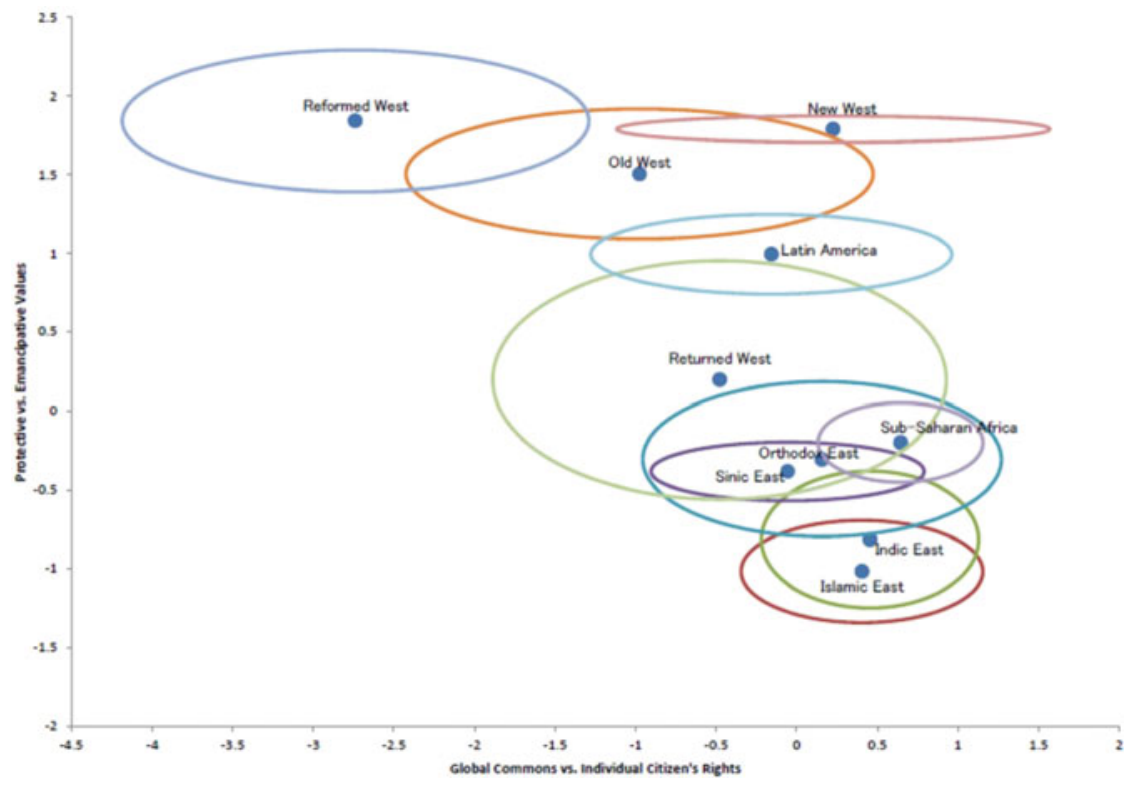

Figure 2a. Ten groups of countries located onto dimensions (Gc-lcr $\times \operatorname{Pr}-E m)$ with partially estimated data 


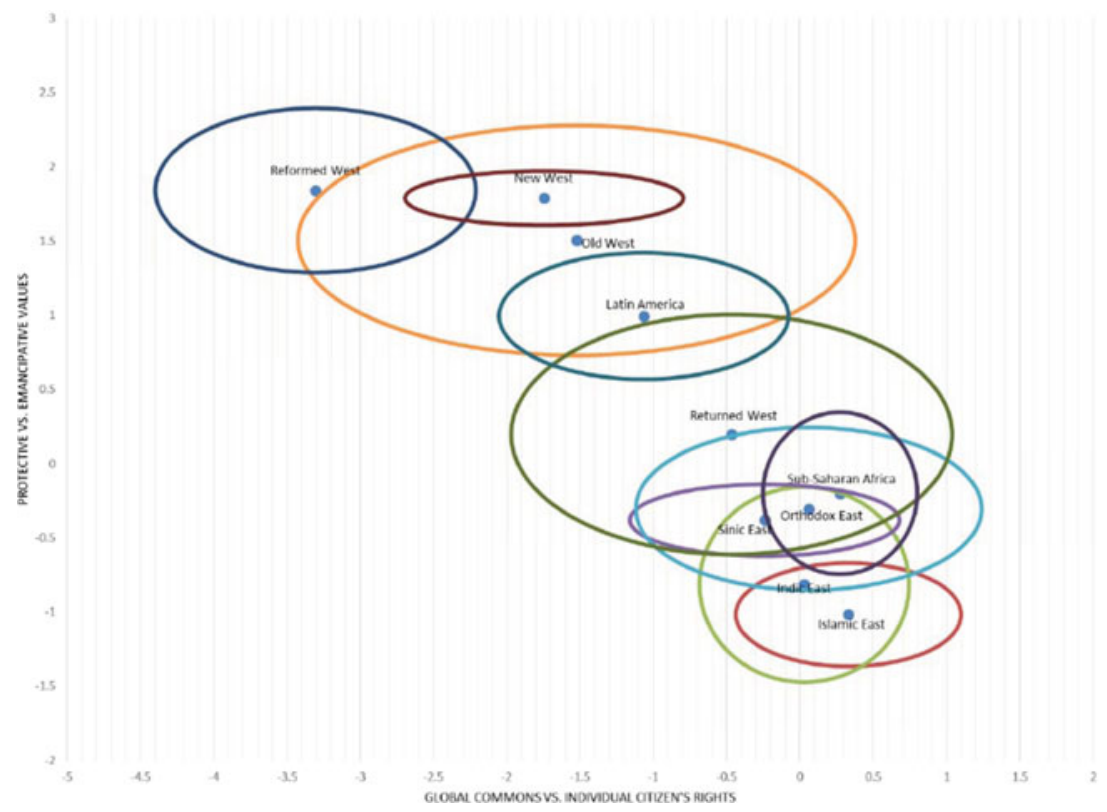

Figure 2b. Ten groups of countries located onto dimensions (Gc-lcr $\times$ Pr-Em) without estimated data

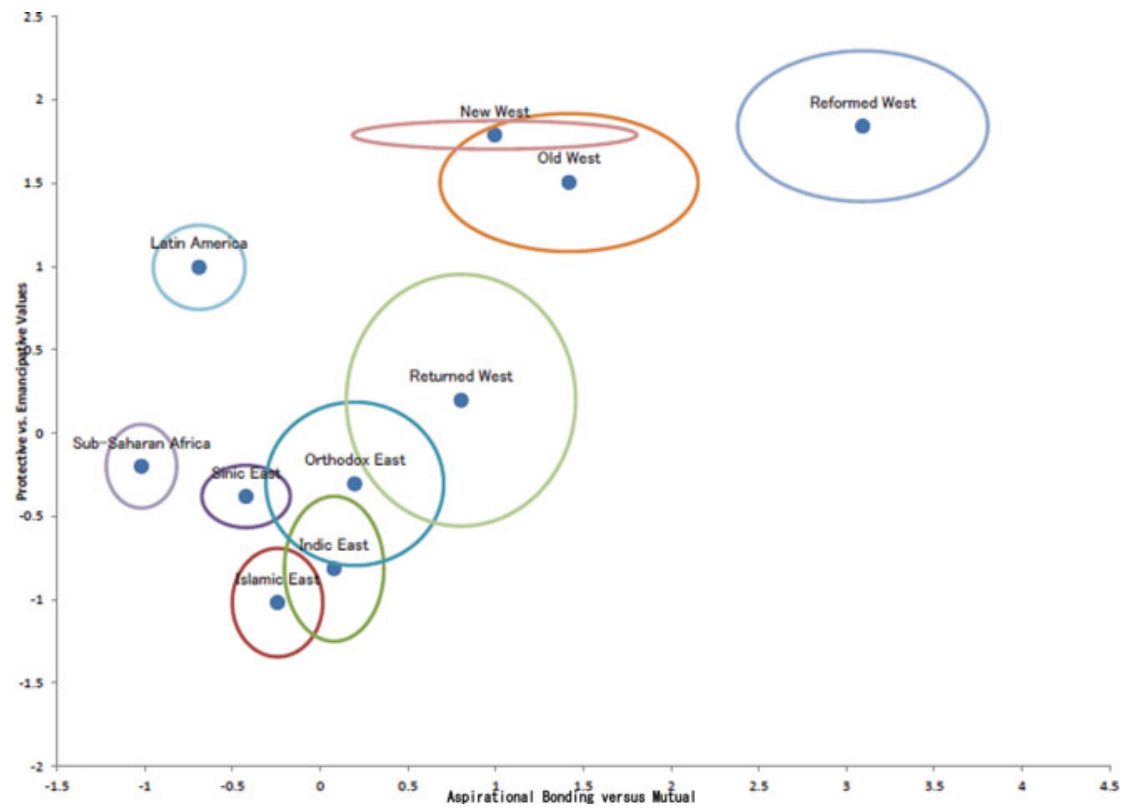

Figure 3a. Ten groups of countries located onto dimensions (Ag-Mb $\times \mathrm{Pr}-\mathrm{Em})$ with partially estimated data 


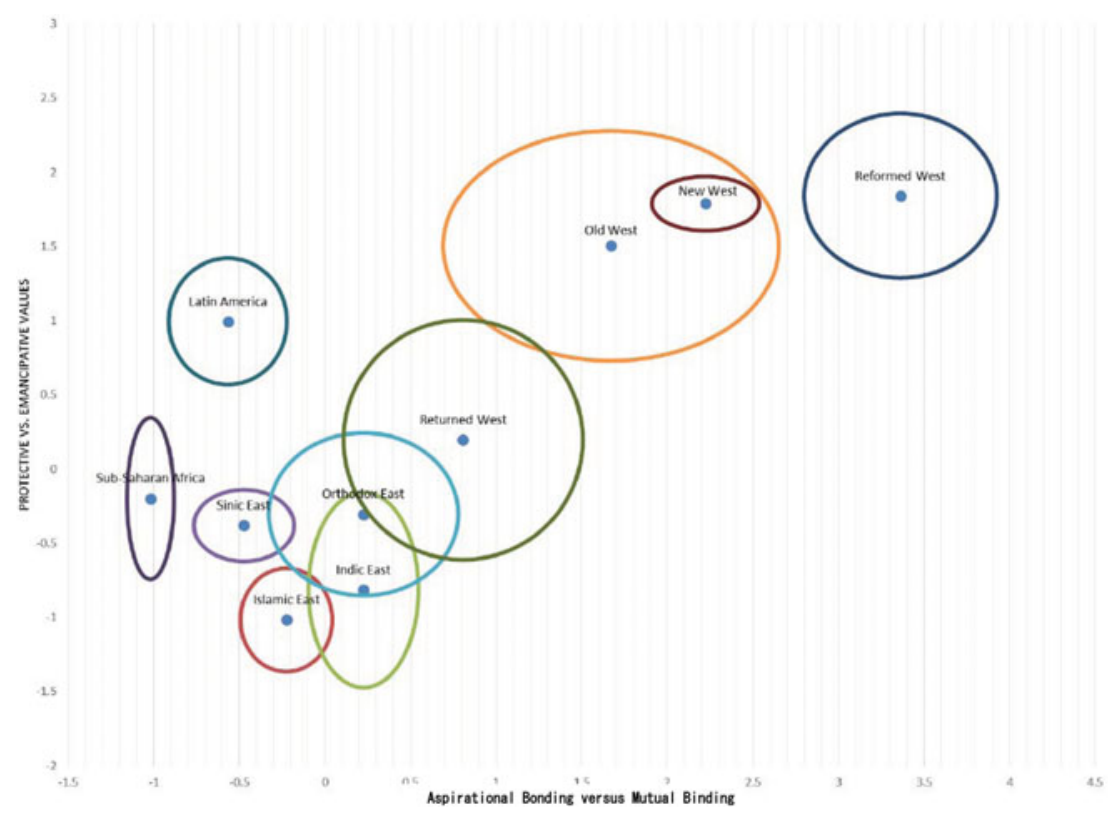

Figure 3b. Ten groups of countries located onto dimensions (Ag-Mb $\times$ Pr-Em) without estimated data

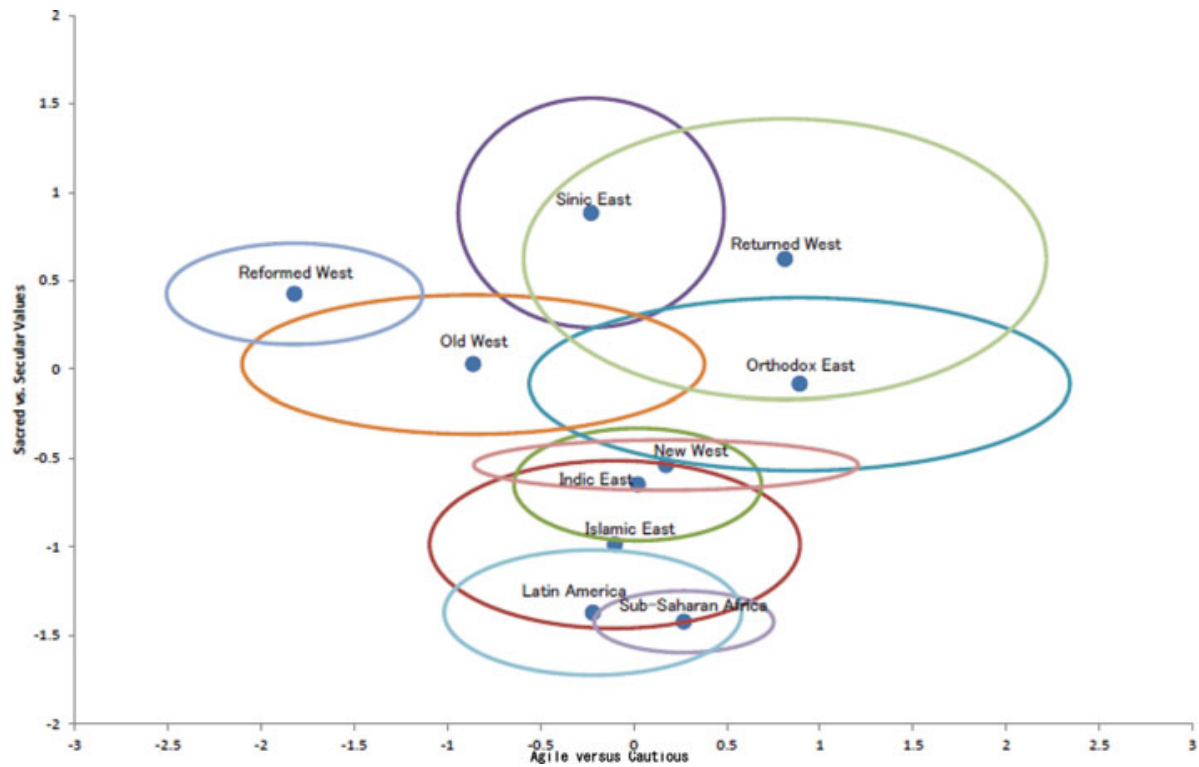

Figure 4a. Ten groups of countries located onto dimensions $(\mathrm{Ag}-\mathrm{Ca} \times \mathrm{Sa}-\mathrm{Se})$ with partially estimated data 


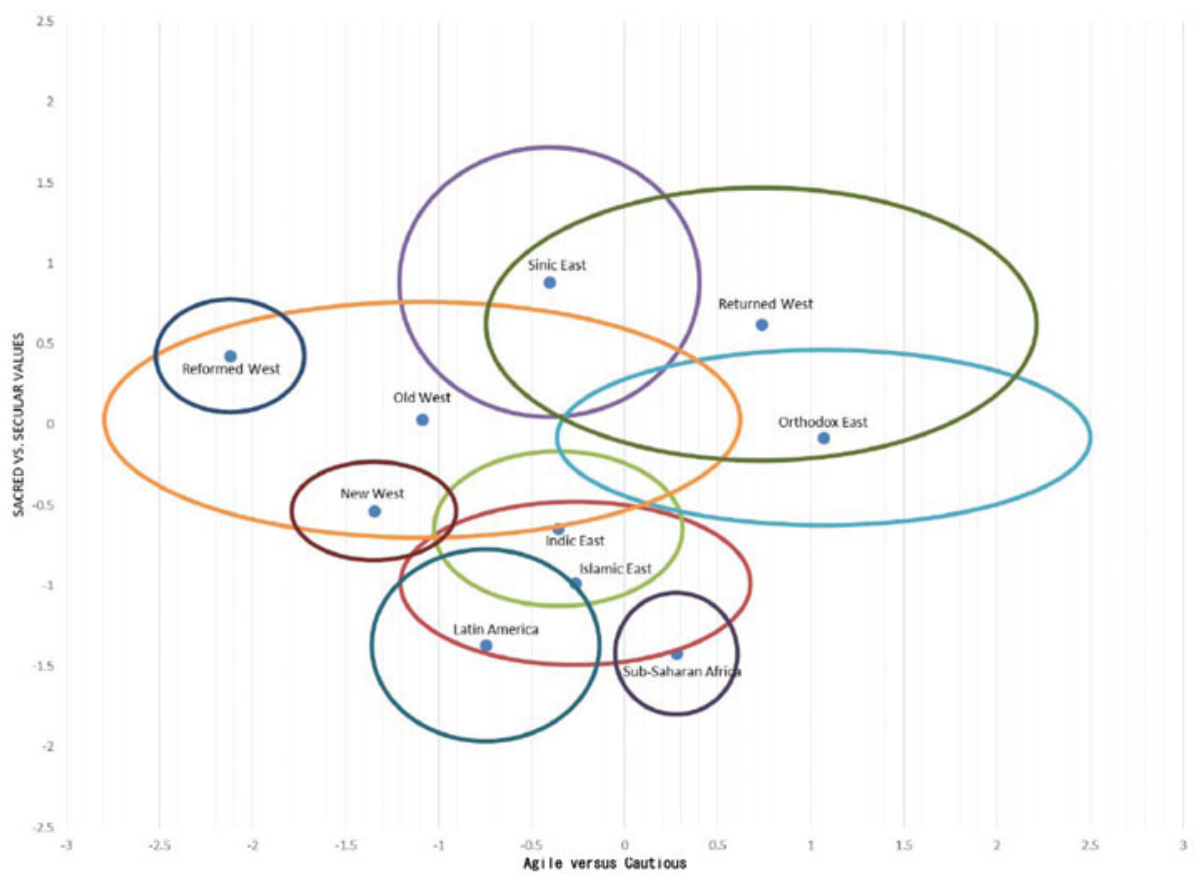

Figure 4b. Ten groups of countries located onto dimensions (Ag-Ca $\times \mathrm{Sa}-\mathrm{Se})$ without estimated data

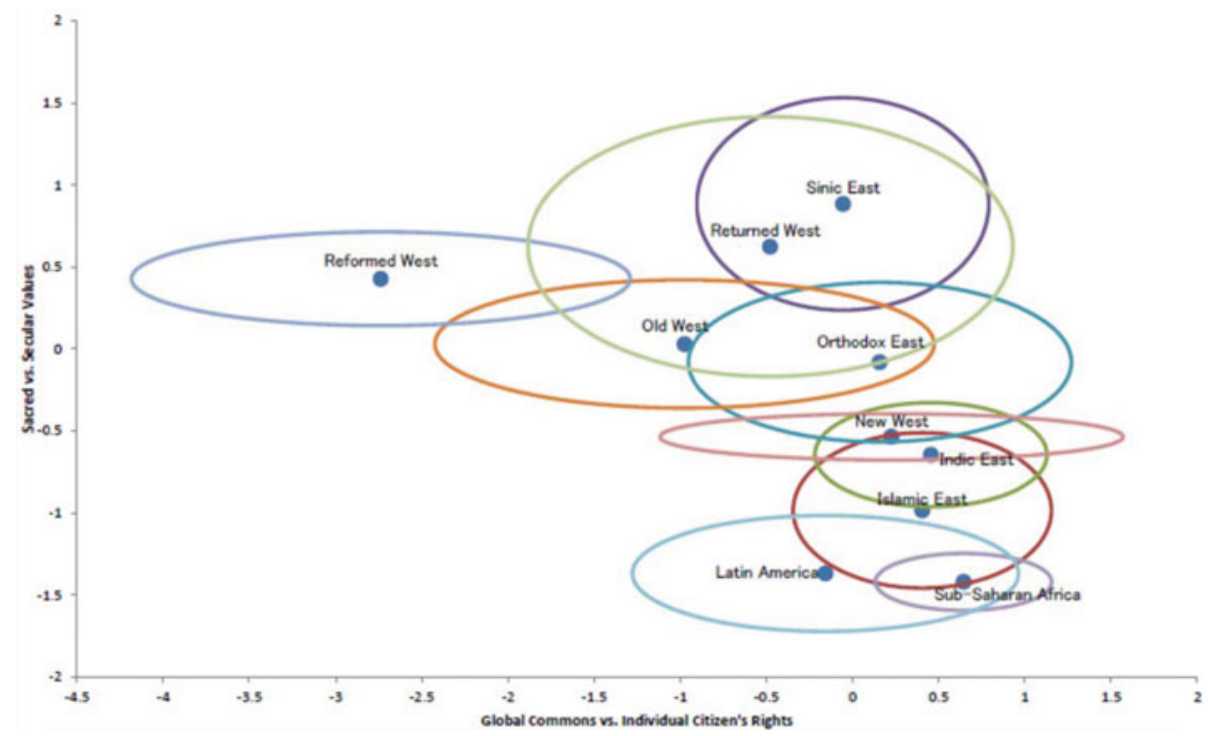

Figure 5a. Ten groups of countries located onto dimensions (Gc-lcr $\times$ Sa-Se) with partially estimated data 


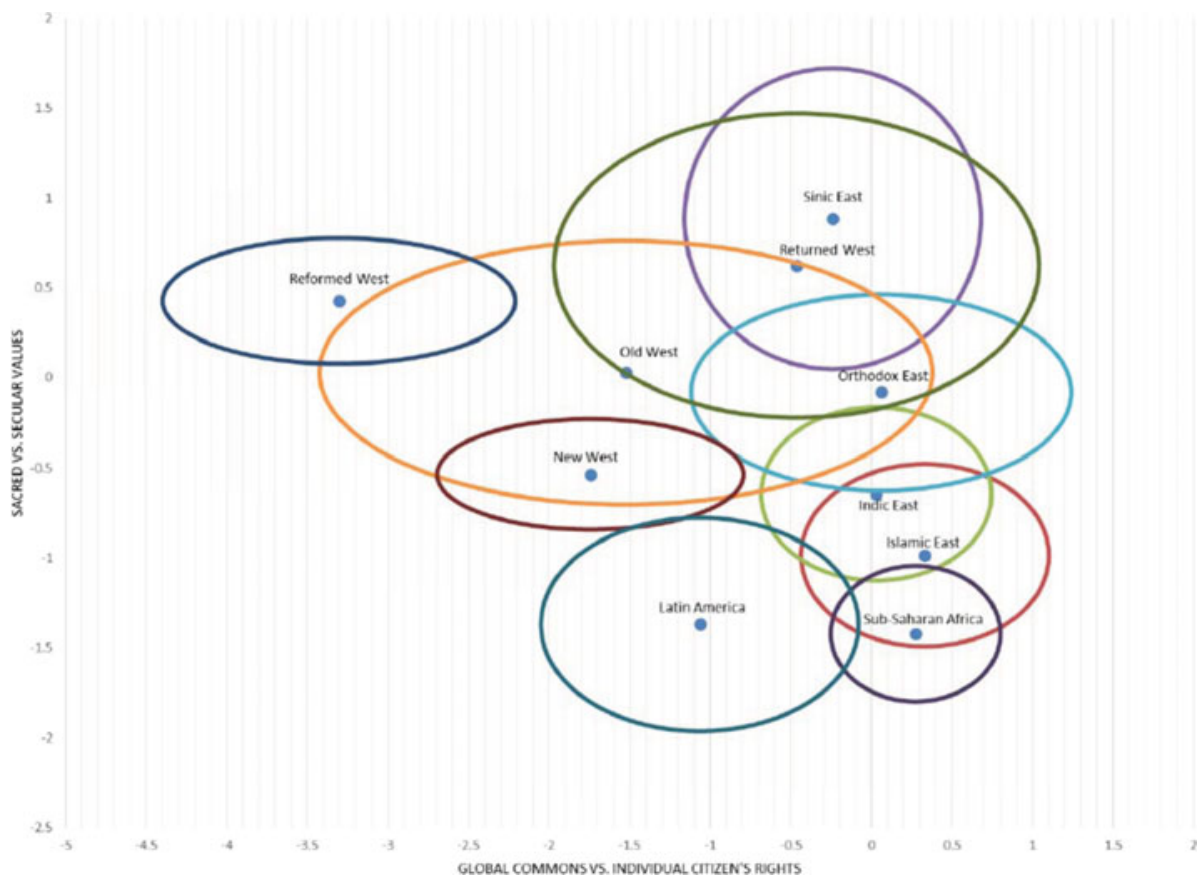

Figure 5b. Ten groups of countries located onto dimensions (Gc-lcr $\times \mathrm{Sa}-\mathrm{Se})$ with partially estimated data

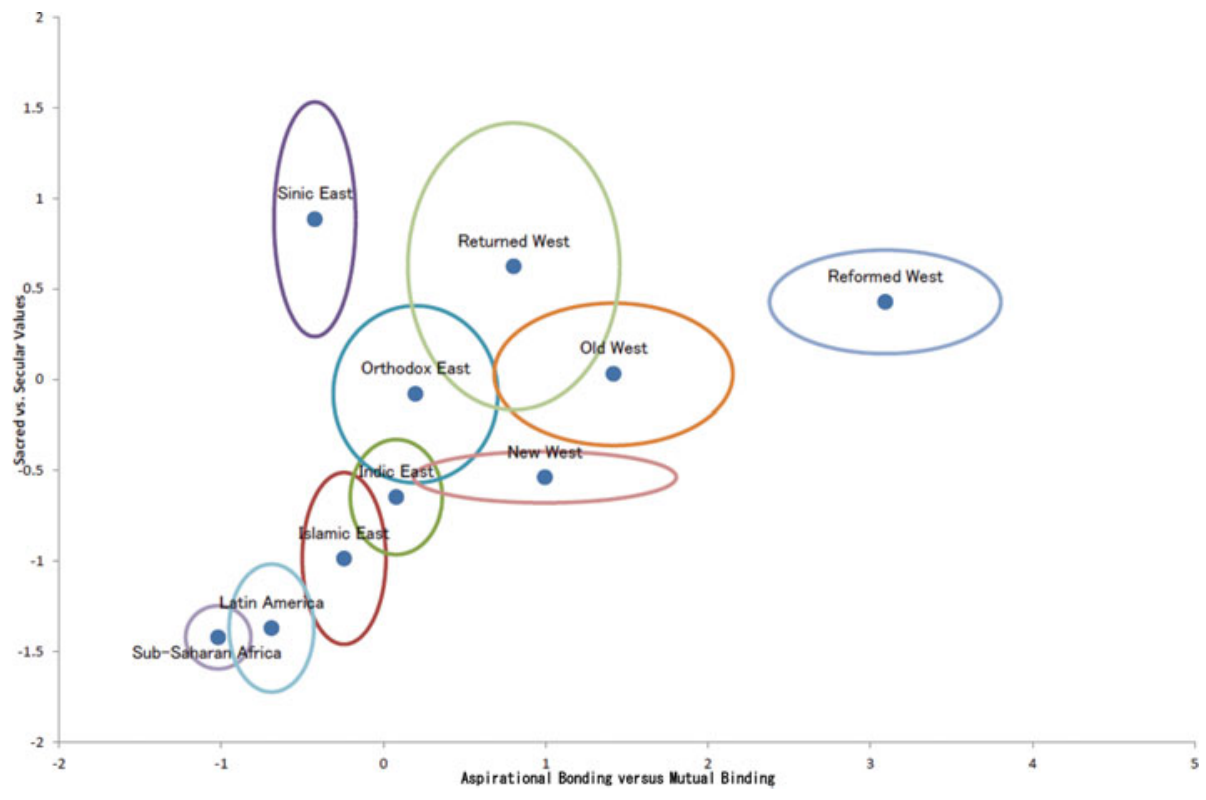

Figure 6a. Ten groups of countries located onto dimensions ( $\mathrm{Ab}-\mathrm{Mb} \times \mathrm{Sa}-\mathrm{Se})$ with partially estimated data 


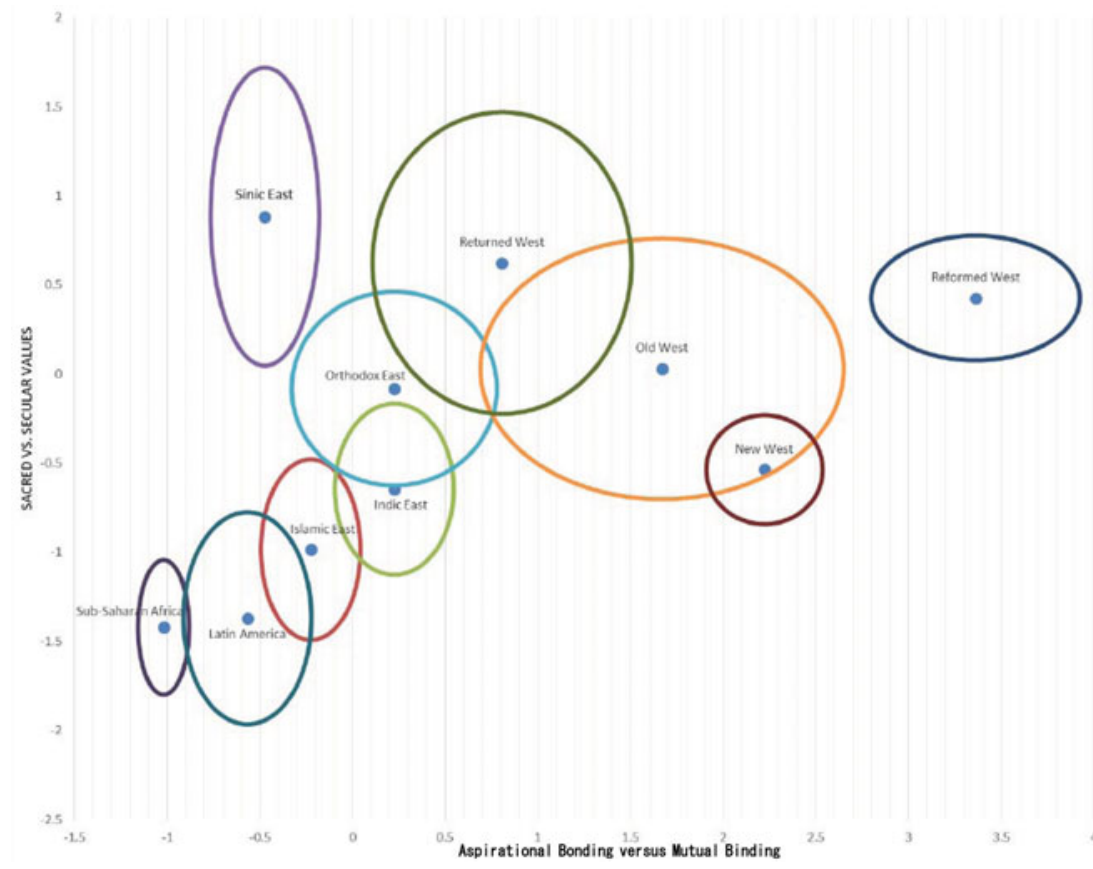

Figure 6b. Ten groups of countries located onto dimensions $(\mathrm{Ab}-\mathrm{Mb} \times \mathrm{Sa}-\mathrm{Se})$ without estimated data

A glance at paired figures on the basis of estimated and pre-estimated data gives a strong evidence about the robustness of estimation. As the six pairs of figures locating the ten groups of nations along key dimensions are compared, one concurs that the locations of the ten groups of countries in the key dimensions are robust.

\section{Conclusion}

We have proposed the concept of the global quasi-legislative processes and outcomes. We have proposed a model linking global citizens' preference and states' participation in multilateral treaties. In constructing our model, we have benefitted from Rousseau's and Locke's metaphors. At the same time, we have found that Rousseau's and Locke's ideas of direct democracy and representative democracy are not easily amenable to operationalization. Rather Rousseau's and Locke's metaphors will continue to help us to envisage a more sophisticated model of global quasi-legislative processes and outcomes. This paper is no more than the first result in our search for global quasi-legislative politics.

\section{Acknowledgement}

Earlier versions of this paper were presented at the Empirical Political Science Research Center Workshop, Tokyo, 28 July 2015; the Hiroshima University Center for Peace Science Research, Hiroshima, 16 October 2015, the Contemporary Normative 
Theory Study Group, Senshu University, Tokyo, 14 November 2015, the Governance Study Project, Ryukoku University, Kyoto, 27 February 2016. I gratefully acknowledge all the constructive comments made. I express my deep gratitude to Professor Christian Welzel for generously giving me access to his factor analysis data of those country scores on key dimensions. Without his help, this article could not have been completed. I am no less grateful to Ambassador Miguel Basanez who not only made me available to his pre-publication book manuscript, A World of Three Cultures, Oxford University Press, and his factor analysis data of those country scores on key dimensions. Due to the temporal proximity, I have used the Welzel data for this paper. I am grateful to Professor Yoshiki Mikami, Vice President, Nagaoka University of Science and Technology, for his unstinting help. Also I must thank Professor Yuichi Kubota, University of Niigata Prefecture, for his help in this project. No less importantly, I express my gratitude to those reviewers of this journal.

\section{About the authors}

Lien Thi Quynh Le received her Ph.D from Nagaoka University of Technology, Japan in March 2015. Her research interests include a wide array of quantitative methods for the analysis and understanding of the global governance. Amongst these, the social network analysis perspective for the understanding of structure and relations between sovereign states, multilateral institutions or international organizations is of particular interest. She is now working as a full-time lecturer at College of Economics, Hue University, Vietnam.

Takashi Inoguchi is Professor Emeritus of the University of Tokyo and President of the University of Niigata Prefecture. He specializes in Japanese politics, comparative political behavior, and international relations. He has published numerous books and articles, amongst which are American Democracy Promotion (co-edited, Oxford University Press, 2000) and The Quality of Life in Asia (co-authored, Springer, 2013). He is Executive Editor of the Japanese Journal of Political Science (Cambridge University Press) and Director of the AsiaBarometer project.

\section{References}

Azuma, Hiroki (2011), General Will 2.o, New York: Vertical, Inc.

Barber, Bejamin (1974), The Death of Communal Liberty: A History of Freedom in a Swiss Mountain Canton, Princeton, NJ: Princeton University Press.

Barber, Benjamin (2004), Strong Democracy: Participators Politics for a New Age, Berkeley, CA: University of California Press.

Basanez, Miguel (2015), A World of Three Cultures: How Values Impact Development, Oxford: Oxford University Press.

Brainard, Lael et al. (2009), Climate Change and Global Poverty: A Billion Lives in the Balance? Brookings Institution Press.

Brenner, Michael (1981/2009), Nuclear Power and Non-Proliferation: The Remaking of US Policy, Cambridge: Cambridge University Press.

Cranston, Maurice William (1985), John Locke: A Biography, Oxford: Oxford University Press.

Drezner, Daniel (2014), The System Worked: How the World Stopped Another Great Great Depression, Oxford: Oxford University Press. 
Dunn, John (ed.) (1994), Democracy: An Unfinished Journey, 508 BC to AD 1993, Oxford: Oxford University Press.

Farr, James and David Lay, Williams (2015), The General Will: The Evolution of a Concept, Cambridge: Cambridge University Press.

Gilani, Ijaz and Takashi, Inoguchi (2013), 'Global and Regional Sampling Theory as Contrasted to Natioal Sampling Theory', paper presented at the World Association of Public Opinion Research, Hong Kong.

Hale, Thomas and David, Held (eds.) (2011), The Handbook of Transnational Governance: Institutions and Innovations, Cambridge: Polity Press.

Huntington, Samuel (1978), 'Transnational Organizations in World Politics', World Politics, 25(3): 333-68.

Inglehart, Ronald (1997), Modernization and Postmodernization: Cultural, Economic and Political Change in 43 Societies, Princeton, NJ: Princeton University Press.

Inglehart, Ronald and Christian, Welzel (2005), Modernization, Cultural Change, and Democracy: The Human Development Sequence, Cambridge: Cambridge University Press.

Inoguchi, Takashi (2015), 'War Occurrence: Hyper-Insecurity and Multilateral Institutions', Japanese Journal of Political Science, 16(3): 388-98.

Jones, Kent (2015), Reconstructing the World Trade Organization for the 21st Century: An Institutional Approach, Oxford: Oxford University Press.

Joyner, Daniel H. (2013), Interpreting the Nuclear Non-Proliferation Treaty, Oxford: Oxford University Press.

Kajima Institute of Peace (2015), Gendai kokusai kankei no kihon monjo (Basic Documents of Contemporary International Relations), Tokyo: Nihon hyoronsha

Keane, John (2009), The Life and Death of Democracy, New York: W.W. Norton.

Krasner, Stephen (ed.) (1983), International Regimes, Ithaca: Cornell University Press.

Kutney, Gerald (2013), Carbon Politics and the Failure of the Kyoto Protocol, London: Routledge.

Le, Lien Q.T., Yoshiki, Mikami and Takashi, Inoguchi (2014), 'Global Leadership and International Regime: Empirical Testing of Cooperation without Hegemony Paradigm on the Basis of 120 Multilateral Conventions Data Deposited to the United Nations System', Japanese Journal of Political Science, 15 (4): 523-601.

McAdam, Doug and Sydney, Tarrow (2001), Dynamics of Contention, Cambridge: Cambridge University Press.

Muthu, Sankar (2015), 'The General Will in Rousseau and after Rousseau', in James Farr and David Lay Williams, The General Will, Cambridge: Cambridge University Press, pp.270-305.

Norris, Pippa and Ronald, Inglehart (2004), Sacred and Secular: Religion and Politics Worldwide, Cambridge: Cambridge University Press.

Popovski, Vesselin and Trudy, Frankel (2014), The Security Council as Global Legislator (Global Institutions), London: Routledge.

Riley, Patrick (2015), 'Kant on the General Will', in James Farr and David Lay Williams (2015), The General Will, pp.333-49.

Shklar, Judith N. (1973), 'General Will', in Philip Wiener (ed.), The Dictionary of the History of Ideas, Charles Scribner's Sons, pp. 275-81.

Solingen, Etel (2013), Regional Orders at Century's Dawn, Princeton, NJ: Princeton University Press.

Sovacool, Benjamin K. and Michael H. Dworkin (2014), Global Energy Justice: Problems, Principles, and Practices, Cambridge: Cambridge University Press.

Sunstein, Cass (2001), Republic.com 2.0, Princeton, NJ: Princeton University Press.

Suzuki, Ken (2013), Namerakana shakai to sono teki (The Soft Society and Its Enemy), Tokyo: Keiso Shobo.

Turkle, Sherry (2012), Alone Together: Why We Expect More from Technology and Less from Each Other, New York: Basic Books.

Volgy, Thomas (1973), 'The Role of the "Outsider" in Quasi-Legislative Systems: The Potential Utility of a Legislative Model', International Organization, 27(1): 85-98.

Welzel, Christian (2013), Freedom Rising: Human Empowerment and the Quest for Emancipation, New York: Cambridge University Press.

Whitehead, Laurence (2002), Democratization: Theory and Experience, Oxford: Oxford University Press.

Yamamoto, Yoshinobu (2008), Kokusai Regime to Governance (International Regimes and Governance), Tokyo: Yuhikaku. 


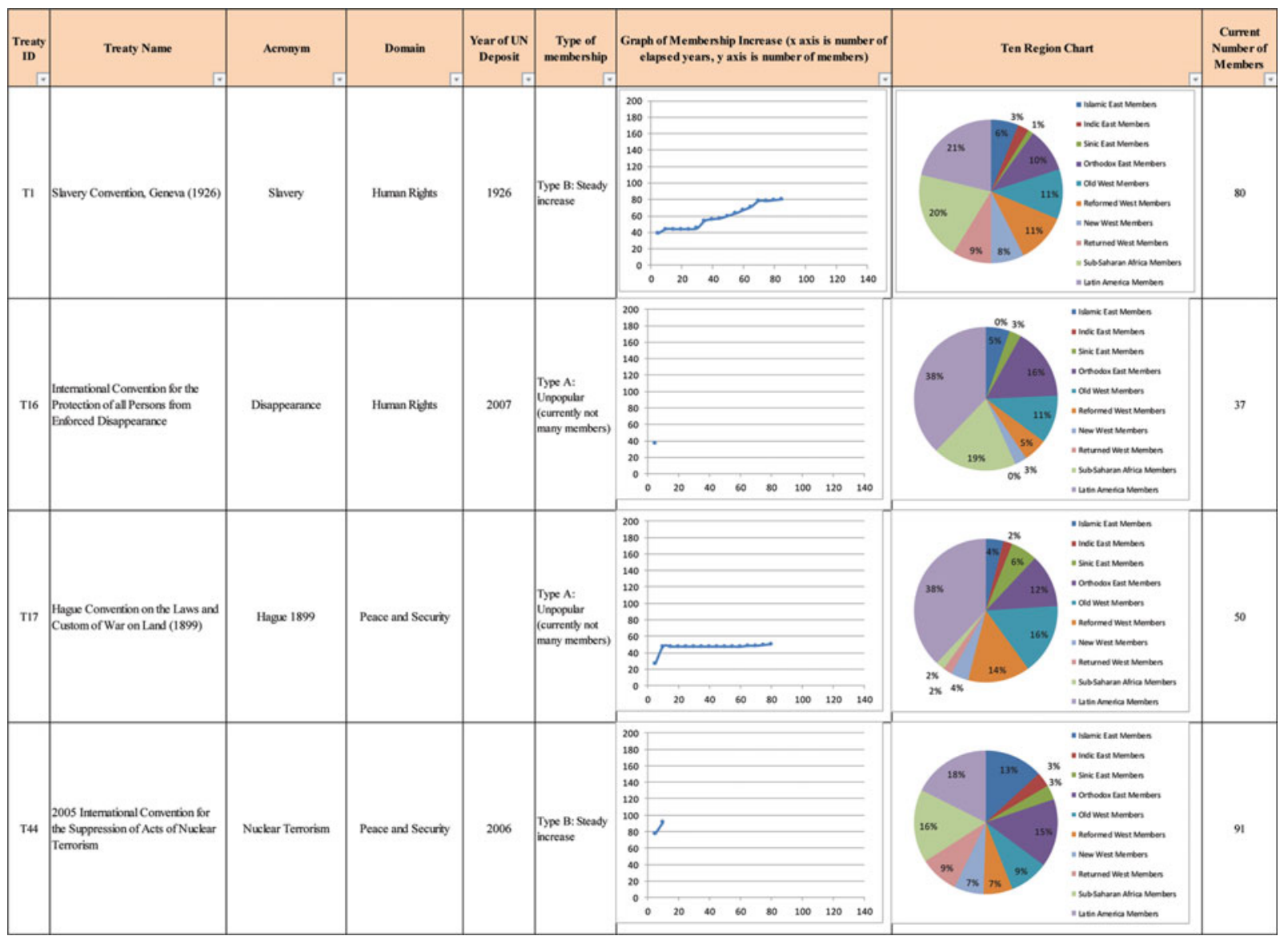

Appendix 1: Six Attributes of Selective Multilateral Treaties (The earliest and latest ones in each of the Six Policy Domains) 


\begin{tabular}{|c|c|c|c|c|c|c|c|}
\hline T46 & $\begin{array}{l}\text { Food and Agiruturue of the Unied } \\
\text { Nations }\end{array}$ & FAO & Emionement & 1945 & $\begin{array}{l}\text { Tye B: Steady } \\
\text { increase }\end{array}$ & 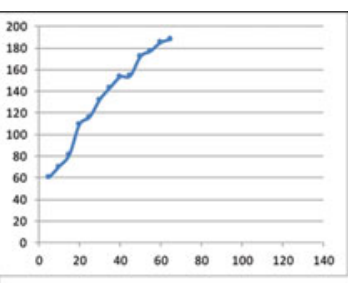 & 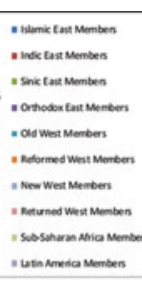 \\
\hline T67 & 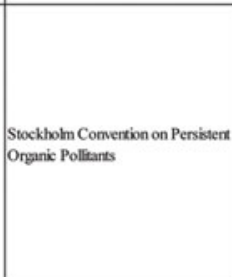 & POPs & Emiroment & 2001 & 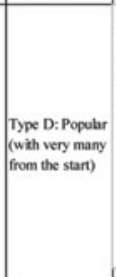 & 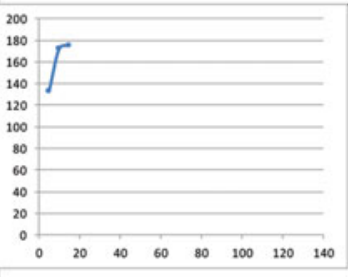 & 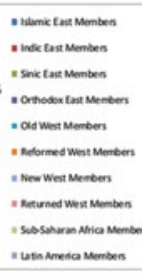 \\
\hline Tos & 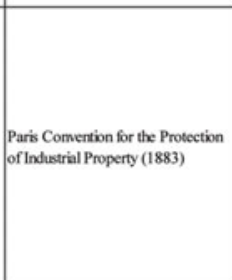 & Paris & Incelectual Property & 1884 & 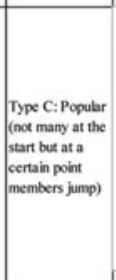 & 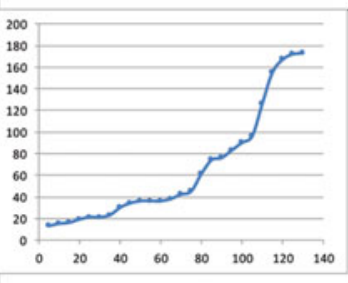 & 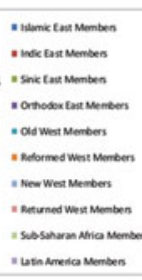 \\
\hline T81 & WIPO Copridist Trealy & wct & Intelictual Property & 2002 & $\begin{array}{l}\text { Type B B Seady } \\
\text { incrase } \\
\end{array}$ & 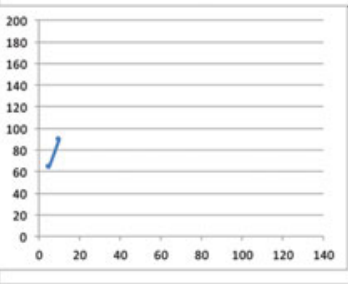 & 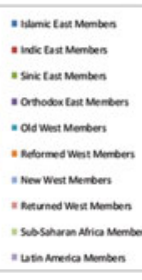 \\
\hline
\end{tabular}




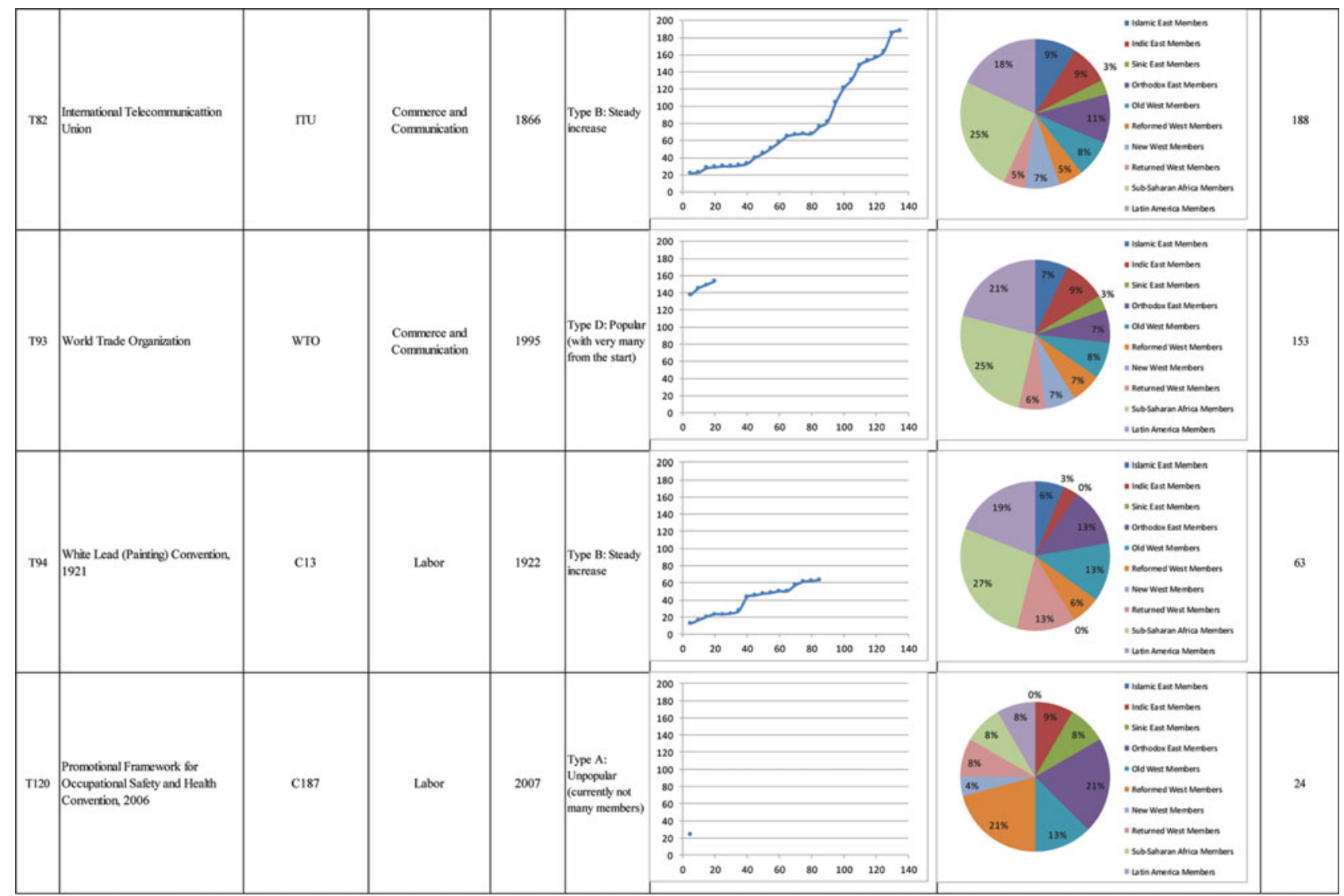

Appendix 1: Continued 
Appendix 2: The Welzel Category (2013) and the modified Welzel Category or the extended Inoguchi/Le Category (2016)

\begin{tabular}{|c|c|c|c|c|c|}
\hline ID & $\begin{array}{l}\text { Country } \\
\text { Name }\end{array}$ & $\begin{array}{l}\text { Country } \\
\text { Code }\end{array}$ & $\begin{array}{l}\text { Welzel } \\
\text { Category }\end{array}$ & $\begin{array}{l}\text { Extended } \\
\text { Inoguchi/Le } \\
\text { Category }\end{array}$ & $\begin{array}{l}\text { Ten Region } \\
\text { Category }\end{array}$ \\
\hline 1 & Afghanistan & AFG & Latin America & & Latin America \\
\hline 2 & Albania & ALB & $\begin{array}{l}\text { Orthodox } \\
\text { East }\end{array}$ & & Orthodox East \\
\hline 3 & Algeria & DZA & Islamic East & & Islamic East \\
\hline 4 & Andorra & ADO & Old West & & Old West \\
\hline 5 & Angola & AGO & & $\begin{array}{l}\text { Sub-Saharan } \\
\text { Africa }\end{array}$ & $\begin{array}{l}\text { Sub-Saharan } \\
\text { Africa }\end{array}$ \\
\hline 6 & $\begin{array}{c}\text { Antigua and } \\
\text { Barbuda }\end{array}$ & ATG & & Latin America & Latin America \\
\hline 7 & Argentina & ARG & & Latin America & Latin America \\
\hline 8 & Armenia & ARM & & Orthodox East & Orthodox East \\
\hline 9 & Australia & AUS & New West & & New West \\
\hline 10 & Austria & AUT & Old West & & Old West \\
\hline 11 & Azerbaijan & AZE & $\begin{array}{l}\text { Orthodox } \\
\text { East }\end{array}$ & & Orthodox East \\
\hline 12 & Bahamas & $\mathrm{BHS}$ & & Latin America & Latin America \\
\hline 13 & Bahrain & $\mathrm{BHR}$ & & Islamic East & Islamic East \\
\hline 14 & Bangladesh & $B G D$ & Indic East & & Indic East \\
\hline 15 & Barbados & BRB & & Latin America & Latin America \\
\hline 16 & Belarus & BLR & $\begin{array}{l}\text { Orthodox } \\
\text { East }\end{array}$ & & Orthodox East \\
\hline 17 & Belgium & BEL & Old West & & Old West \\
\hline 18 & Belize & $\mathrm{BLZ}$ & & Latin America & Latin America \\
\hline 19 & Benin & BEN & & $\begin{array}{l}\text { Sub-Saharan } \\
\text { Africa }\end{array}$ & $\begin{array}{l}\text { Sub-Saharan } \\
\text { Africa }\end{array}$ \\
\hline 20 & Bhutan & BTN & & Indic East & Indic East \\
\hline 21 & Bolivia & $\mathrm{BOL}$ & & Latin America & Latin America \\
\hline 22 & $\begin{array}{l}\text { Bosnia and } \\
\text { Herzegov- } \\
\text { ina }\end{array}$ & $\mathrm{BIH}$ & $\begin{array}{l}\text { Orthodox } \\
\text { East }\end{array}$ & & Orthodox East \\
\hline 23 & Botswana & BWA & & $\begin{array}{l}\text { Sub-Saharan } \\
\text { Africa }\end{array}$ & $\begin{array}{l}\text { Sub-Saharan } \\
\text { Africa }\end{array}$ \\
\hline 24 & Brazil & BRA & Latin America & & Latin America \\
\hline 25 & $\begin{array}{l}\text { Brunei Darus- } \\
\text { salam }\end{array}$ & BRN & & Indic East & Indic East \\
\hline 26 & Bulgaria & BGR & & Orthodox East & Orthodox East \\
\hline 27 & Burkina Faso & BFA & $\begin{array}{l}\text { Sub-Saharan } \\
\text { Africa }\end{array}$ & & $\begin{array}{l}\text { Sub-Saharan } \\
\text { Africa }\end{array}$ \\
\hline 28 & Burundi & BDI & & $\begin{array}{l}\text { Sub-Saharan } \\
\text { Africa }\end{array}$ & $\begin{array}{l}\text { Sub-Saharan } \\
\text { Africa }\end{array}$ \\
\hline 29 & Cambodia & KHM & & Indic East & Indic East \\
\hline 30 & Cameroon & CMR & & $\begin{array}{l}\text { Sub-Saharan } \\
\text { Africa }\end{array}$ & $\begin{array}{l}\text { Sub-Saharan } \\
\text { Africa }\end{array}$ \\
\hline
\end{tabular}


Appendix 2: Continued

\begin{tabular}{|c|c|c|c|c|c|}
\hline ID & $\begin{array}{l}\text { Country } \\
\text { Name }\end{array}$ & $\begin{array}{l}\text { Country } \\
\text { Code }\end{array}$ & $\begin{array}{l}\text { Welzel } \\
\text { Category }\end{array}$ & $\begin{array}{l}\text { Extended } \\
\text { Inoguchi/Le } \\
\text { Category }\end{array}$ & $\begin{array}{l}\text { Ten Region } \\
\text { Category }\end{array}$ \\
\hline 31 & Cape Verde & CPV & & $\begin{array}{l}\text { Sub-Saharan } \\
\text { Africa }\end{array}$ & $\begin{array}{l}\text { Sub-Saharan } \\
\text { Africa }\end{array}$ \\
\hline 32 & Canada & CAN & New West & & New West \\
\hline 33 & $\begin{array}{l}\text { Central } \\
\text { African } \\
\text { Republic }\end{array}$ & $\mathrm{CAF}$ & & $\begin{array}{l}\text { Sub-Saharan } \\
\text { Africa }\end{array}$ & $\begin{array}{l}\text { Sub-Saharan } \\
\text { Africa }\end{array}$ \\
\hline 34 & Chad & TCD & & $\begin{array}{l}\text { Sub-Saharan } \\
\text { Africa }\end{array}$ & $\begin{array}{l}\text { Sub-Saharan } \\
\text { Africa }\end{array}$ \\
\hline 35 & Chile & $\mathrm{CHL}$ & Latin America & & Latin America \\
\hline 36 & China & $\mathrm{CHN}$ & Sinic East & & Sinic East \\
\hline 37 & Colombia & $\mathrm{COL}$ & Latin America & & Latin America \\
\hline 38 & Comoros & COM & & $\begin{array}{l}\text { Sub-Saharan } \\
\text { Africa }\end{array}$ & $\begin{array}{l}\text { Sub-Saharan } \\
\text { Africa }\end{array}$ \\
\hline 39 & Congo & COG & & $\begin{array}{l}\text { Sub-Saharan } \\
\text { Africa }\end{array}$ & $\begin{array}{l}\text { Sub-Saharan } \\
\text { Africa }\end{array}$ \\
\hline 40 & Costa Rica & CRI & Latin America & & Latin America \\
\hline 41 & Cote d'Ivoire & CIV & & $\begin{array}{l}\text { Sub-Saharan } \\
\text { Africa }\end{array}$ & $\begin{array}{l}\text { Sub-Saharan } \\
\text { Africa }\end{array}$ \\
\hline 42 & Croatia & HRV & $\begin{array}{c}\text { Returned } \\
\text { West }\end{array}$ & & Returned West \\
\hline 43 & Cuba & CUB & & Latin America & Latin America \\
\hline 44 & Cyprus & CYP & Old West & & Old West \\
\hline 45 & $\begin{array}{l}\text { Czech } \\
\text { Republic }\end{array}$ & CZE & $\begin{array}{l}\text { Returned } \\
\text { West }\end{array}$ & & Returned West \\
\hline 46 & $\begin{array}{l}\text { Democratic } \\
\text { People's } \\
\text { Republic of } \\
\text { Korea }\end{array}$ & PRK & & Sinic East & Sinic East \\
\hline 47 & $\begin{array}{l}\text { Democratic } \\
\text { Republic of } \\
\text { the Congo }\end{array}$ & ZAR & & $\begin{array}{l}\text { Sub-Saharan } \\
\text { Africa }\end{array}$ & $\begin{array}{l}\text { Sub-Saharan } \\
\text { Africa }\end{array}$ \\
\hline 48 & Denmark & DNK & $\begin{array}{l}\text { Reformed } \\
\text { West }\end{array}$ & & Reformed West \\
\hline 49 & Djibouti & DIJ & & $\begin{array}{l}\text { Sub-Saharan } \\
\text { Africa }\end{array}$ & $\begin{array}{l}\text { Sub-Saharan } \\
\text { Africa }\end{array}$ \\
\hline 50 & Dominica & DMA & & Latin America & Latin America \\
\hline 51 & $\begin{array}{l}\text { Dominican } \\
\text { Republic }\end{array}$ & DOM & & Latin America & Latin America \\
\hline 52 & Ecuador & ECU & & Latin America & Latin America \\
\hline 53 & Egypt & EGY & Islamic East & & Islamic East \\
\hline 54 & El Salvador & SLV & Latin America & & Latin America \\
\hline 55 & $\begin{array}{c}\text { Equatorial } \\
\text { Guinea }\end{array}$ & GNO & & Latin America & Latin America \\
\hline
\end{tabular}


Appendix 2: Continued

\begin{tabular}{|c|c|c|c|c|c|}
\hline ID & $\begin{array}{l}\text { Country } \\
\text { Name }\end{array}$ & $\begin{array}{l}\text { Country } \\
\text { Code }\end{array}$ & $\begin{array}{l}\text { Welzel } \\
\text { Category }\end{array}$ & $\begin{array}{l}\text { Extended } \\
\text { Inoguchi/Le } \\
\text { Category }\end{array}$ & $\begin{array}{l}\text { Ten Region } \\
\text { Category }\end{array}$ \\
\hline 56 & Eritrea & ERI & & $\begin{array}{l}\text { Sub-Saharan } \\
\text { Africa }\end{array}$ & $\begin{array}{l}\text { Sub-Saharan } \\
\text { Africa }\end{array}$ \\
\hline 57 & Estonia & EST & $\begin{array}{l}\text { Returned } \\
\text { West }\end{array}$ & & Returned West \\
\hline 58 & Ethiopia & ETH & & $\begin{array}{l}\text { Sub-Saharan } \\
\text { Africa }\end{array}$ & $\begin{array}{l}\text { Sub-Saharan } \\
\text { Africa }\end{array}$ \\
\hline 59 & Fiji & FJI & & New West & New West \\
\hline 60 & Finland & FIN & $\begin{array}{l}\text { Reformed } \\
\text { West }\end{array}$ & & Reformed West \\
\hline 61 & France & FRA & Old West & & Old West \\
\hline 62 & Gabon & GAB & & $\begin{array}{l}\text { Sub-Saharan } \\
\text { Africa }\end{array}$ & $\begin{array}{l}\text { Sub-Saharan } \\
\text { Africa }\end{array}$ \\
\hline 63 & Gambia & GMB & & $\begin{array}{l}\text { Sub-Saharan } \\
\text { Africa }\end{array}$ & $\begin{array}{l}\text { Sub-Saharan } \\
\text { Africa }\end{array}$ \\
\hline 64 & Georgia & GEO & $\begin{array}{l}\text { Orthodox } \\
\text { East }\end{array}$ & & Orthodox East \\
\hline 65 & Germany & DEU & $\begin{array}{l}\text { Reformed } \\
\text { West }\end{array}$ & & Reformed West \\
\hline 66 & Ghana & $\mathrm{GHA}$ & $\begin{array}{l}\text { Sub-Saharan } \\
\text { Africa }\end{array}$ & & $\begin{array}{l}\text { Sub-Saharan } \\
\text { Africa }\end{array}$ \\
\hline 67 & Greece & GRC & Old West & & Old West \\
\hline 68 & Grenada & GRD & & Latin America & Latin America \\
\hline 69 & Guatemala & GTM & Latin America & & Latin America \\
\hline 70 & Guinea & GIN & & $\begin{array}{l}\text { Sub-Saharan } \\
\text { Africa }\end{array}$ & $\begin{array}{l}\text { Sub-Saharan } \\
\text { Africa }\end{array}$ \\
\hline 71 & $\begin{array}{l}\text { Guinea- } \\
\text { Bissau }\end{array}$ & GNB & & $\begin{array}{l}\text { Sub-Saharan } \\
\text { Africa }\end{array}$ & $\begin{array}{l}\text { Sub-Saharan } \\
\text { Africa }\end{array}$ \\
\hline 72 & Guyana & GUY & & Latin America & Latin America \\
\hline 73 & Haiti & $\mathrm{HTI}$ & & Latin America & Latin America \\
\hline 74 & Honduras & HND & & Latin America & Latin America \\
\hline 75 & Hungary & HUN & $\begin{array}{l}\text { Returned } \\
\text { West }\end{array}$ & & Returned West \\
\hline 76 & Iceland & ISL & $\begin{array}{l}\text { Reformed } \\
\text { West }\end{array}$ & & Reformed West \\
\hline 77 & India & IND & Indic East & & Indic East \\
\hline 78 & Indonesia & IDN & Indic East & & Indic East \\
\hline 79 & Iran & IRN & Islamic East & & Islamic East \\
\hline 80 & Iraq & IRQ & Islamic East & & Islamic East \\
\hline 81 & Ireland & $\mathrm{IRL}$ & $\begin{array}{l}\text { Reformed } \\
\text { West }\end{array}$ & & Reformed West \\
\hline 82 & Israel & ISR & Old West & & Old West \\
\hline 83 & Italy & ITA & Old West & & Old West \\
\hline 84 & Jamaica & JAM & & Latin America & Latin America \\
\hline
\end{tabular}


Appendix 2: Continued

\begin{tabular}{|c|c|c|c|c|c|}
\hline ID & $\begin{array}{l}\text { Country } \\
\text { Name }\end{array}$ & $\begin{array}{l}\text { Country } \\
\text { Code }\end{array}$ & $\begin{array}{l}\text { Welzel } \\
\text { Category }\end{array}$ & $\begin{array}{l}\text { Extended } \\
\text { Inoguchi/Le } \\
\text { Category }\end{array}$ & $\begin{array}{l}\text { Ten Region } \\
\text { Category }\end{array}$ \\
\hline 85 & Japan & JPN & Sinic East & & Sinic East \\
\hline 86 & Jordan & JOR & Islamic East & & Islamic East \\
\hline 87 & Kazakhstan & $K A Z$ & & Orthodox East & Orthodox East \\
\hline 88 & Kenya & KEN & & $\begin{array}{l}\text { Sub-Saharan } \\
\text { Africa }\end{array}$ & $\begin{array}{l}\text { Sub-Saharan } \\
\text { Africa }\end{array}$ \\
\hline 89 & Kiribati & KIR & & New West & New West \\
\hline 90 & Kuwait & KWT & & Islamic East & Islamic East \\
\hline 91 & Kyrgyzstan & $K G Z$ & $\begin{array}{l}\text { Orthodox } \\
\text { East }\end{array}$ & & Orthodox East \\
\hline 92 & $\begin{array}{c}\text { Lao People's } \\
\text { Democratic } \\
\text { Republic }\end{array}$ & LAO & & Indic East & Indic East \\
\hline 93 & Latvia & LVA & $\begin{array}{c}\text { Returned } \\
\text { West }\end{array}$ & & Returned West \\
\hline 94 & Lebanon & LBN & & Islamic East & Islamic East \\
\hline 95 & Lesotho & LSO & & $\begin{array}{l}\text { Sub-Saharan } \\
\text { Africa }\end{array}$ & $\begin{array}{l}\text { Sub-Saharan } \\
\text { Africa }\end{array}$ \\
\hline 96 & Liberia & LBR & & $\begin{array}{l}\text { Sub-Saharan } \\
\text { Africa }\end{array}$ & $\begin{array}{l}\text { Sub-Saharan } \\
\text { Africa }\end{array}$ \\
\hline 97 & $\begin{array}{l}\text { Libyan Arab } \\
\text { Jamahiriya }\end{array}$ & LBY & & Islamic East & Islamic East \\
\hline 98 & Liechtenstein & LIE & & Old West & Old West \\
\hline 99 & Lithuania & LTU & $\begin{array}{c}\text { Returned } \\
\text { West }\end{array}$ & & Returned West \\
\hline 100 & Luxembourg & LUX & Old West & & Old West \\
\hline 101 & Madagascar & $M D G$ & & $\begin{array}{l}\text { Sub-Saharan } \\
\text { Africa }\end{array}$ & $\begin{array}{l}\text { Sub-Saharan } \\
\text { Africa }\end{array}$ \\
\hline 102 & Malawi & MWI & & $\begin{array}{l}\text { Sub-Saharan } \\
\text { Africa }\end{array}$ & $\begin{array}{l}\text { Sub-Saharan } \\
\text { Africa }\end{array}$ \\
\hline 103 & Malaysia & MYS & Indic East & & Indic East \\
\hline 104 & Maldives & MDV & & Indic East & Indic East \\
\hline 105 & Mali & MLI & $\begin{array}{l}\text { Sub-Saharan } \\
\text { Africa }\end{array}$ & & $\begin{array}{l}\text { Sub-Saharan } \\
\text { Africa }\end{array}$ \\
\hline 106 & Malta & MLT & Old West & & Old West \\
\hline 107 & $\begin{array}{l}\text { Marshall } \\
\text { Islands }\end{array}$ & MHL & & New West & New West \\
\hline 108 & Mauritania & MRT & & $\begin{array}{l}\text { Sub-Saharan } \\
\text { Africa }\end{array}$ & $\begin{array}{l}\text { Sub-Saharan } \\
\text { Africa }\end{array}$ \\
\hline 109 & Mauritius & MUS & & $\begin{array}{l}\text { Sub-Saharan } \\
\text { Africa }\end{array}$ & $\begin{array}{l}\text { Sub-Saharan } \\
\text { Africa }\end{array}$ \\
\hline 110 & Mexico & MEX & Latin America & & Latin America \\
\hline 111 & Monaco & $\mathrm{MCO}$ & & Old West & Old West \\
\hline
\end{tabular}


Appendix 2: Continued

\begin{tabular}{|c|c|c|c|c|c|}
\hline ID & $\begin{array}{l}\text { Country } \\
\text { Name }\end{array}$ & $\begin{array}{l}\text { Country } \\
\text { Code }\end{array}$ & $\begin{array}{l}\text { Welzel } \\
\text { Category }\end{array}$ & $\begin{array}{l}\text { Extended } \\
\text { Inoguchi/Le } \\
\text { Category }\end{array}$ & $\begin{array}{l}\text { Ten Region } \\
\text { Category }\end{array}$ \\
\hline 112 & Mongolia & MNG & & Sinic East & Sinic East \\
\hline 113 & Montenegro & MNE & $\begin{array}{l}\text { Orthodox } \\
\text { East }\end{array}$ & & Orthodox East \\
\hline 114 & Morocco & MAR & Islamic East & & Islamic East \\
\hline 115 & Mozambique & MOZ & & $\begin{array}{l}\text { Sub-Saharan } \\
\text { Africa }\end{array}$ & $\begin{array}{l}\text { Sub-Saharan } \\
\text { Africa }\end{array}$ \\
\hline 116 & Myanmar & MMR & & Indic East & Indic East \\
\hline 117 & Namibia & NAM & & $\begin{array}{l}\text { Sub-Saharan } \\
\text { Africa }\end{array}$ & $\begin{array}{l}\text { Sub-Saharan } \\
\text { Africa }\end{array}$ \\
\hline 118 & Nauru & NRU & & New West & New West \\
\hline 119 & Nepal & NPL & & Indic East & Indic East \\
\hline 120 & Netherlands & NLD & $\begin{array}{l}\text { Reformed } \\
\text { West }\end{array}$ & & Reformed West \\
\hline 121 & New Zealand & NZL & New West & & New West \\
\hline 122 & Nicaragua & $\mathrm{NIC}$ & & Latin America & Latin America \\
\hline 123 & Niger & NER & & $\begin{array}{l}\text { Sub-Saharan } \\
\text { Africa }\end{array}$ & $\begin{array}{l}\text { Sub-Saharan } \\
\text { Africa }\end{array}$ \\
\hline 124 & Nigeria & NGA & $\begin{array}{l}\text { Sub-Saharan } \\
\text { Africa }\end{array}$ & & $\begin{array}{l}\text { Sub-Saharan } \\
\text { Africa }\end{array}$ \\
\hline 125 & Norway & NOR & $\begin{array}{l}\text { Reformed } \\
\text { West }\end{array}$ & & Reformed West \\
\hline 126 & Oman & OMN & & Islamic East & Islamic East \\
\hline 127 & Pakistan & PAK & Indic East & & Indic East \\
\hline 128 & Palau & PLW & & New West & New West \\
\hline 129 & Panama & PAN & & Latin America & Latin America \\
\hline 130 & $\begin{array}{l}\text { Papua New } \\
\text { Guinea }\end{array}$ & PNG & & New West & New West \\
\hline 131 & Paraguay & PRY & & Latin America & Latin America \\
\hline 132 & Peru & PER & Latin America & & Latin America \\
\hline 133 & Philippines & $\mathrm{PHL}$ & Indic East & & Indic East \\
\hline 134 & Poland & $\mathrm{POL}$ & $\begin{array}{l}\text { Returned } \\
\text { West }\end{array}$ & & Returned West \\
\hline 135 & Portugal & PRT & Old West & & Old West \\
\hline 136 & Qatar & QAT & & Islamic East & Islamic East \\
\hline 137 & $\begin{array}{l}\text { Republic of } \\
\text { Korea }\end{array}$ & KOR & Sinic East & & Sinic East \\
\hline 138 & $\begin{array}{c}\text { Republic of } \\
\text { Moldova }\end{array}$ & MDA & $\begin{array}{l}\text { Orthodox } \\
\text { East }\end{array}$ & & Orthodox East \\
\hline 139 & Romania & ROM & $\begin{array}{l}\text { Orthodox } \\
\text { East }\end{array}$ & & Orthodox East \\
\hline 140 & $\begin{array}{l}\text { Russian } \\
\text { Federation }\end{array}$ & RUS & $\begin{array}{l}\text { Orthodox } \\
\text { East }\end{array}$ & & Orthodox East \\
\hline 141 & Rwanda & RWA & $\begin{array}{l}\text { Sub-Saharan } \\
\text { Africa }\end{array}$ & & $\begin{array}{l}\text { Sub-Saharan } \\
\text { Africa }\end{array}$ \\
\hline
\end{tabular}


Appendix 2: Continued

\begin{tabular}{|c|c|c|c|c|c|}
\hline ID & $\begin{array}{l}\text { Country } \\
\text { Name }\end{array}$ & $\begin{array}{l}\text { Country } \\
\text { Code }\end{array}$ & $\begin{array}{l}\text { Welzel } \\
\text { Category }\end{array}$ & $\begin{array}{l}\text { Extended } \\
\text { Inoguchi/Le } \\
\text { Category }\end{array}$ & $\begin{array}{l}\text { Ten Region } \\
\text { Category }\end{array}$ \\
\hline 142 & $\begin{array}{l}\text { Saint Kitts } \\
\text { and Nevis }\end{array}$ & KNA & & Latin America & Latin America \\
\hline 143 & Saint Lucia & LCA & & Latin America & Latin America \\
\hline 144 & $\begin{array}{l}\text { Saint Vincent } \\
\text { and the } \\
\text { Grenad- } \\
\text { ines }\end{array}$ & VCT & & Latin America & Latin America \\
\hline 145 & Samoa & WSM & & New West & New West \\
\hline 146 & San Marino & SMR & & Old West & Old West \\
\hline 147 & $\begin{array}{l}\text { Sao Tome } \\
\text { and } \\
\text { Principe }\end{array}$ & STP & & $\begin{array}{l}\text { Sub-Saharan } \\
\text { Africa }\end{array}$ & $\begin{array}{l}\text { Sub-Saharan } \\
\text { Africa }\end{array}$ \\
\hline 148 & Saudi Arabia & SAU & Islamic East & & Islamic East \\
\hline 149 & Senegal & SEN & & $\begin{array}{l}\text { Sub-Saharan } \\
\text { Africa }\end{array}$ & $\begin{array}{l}\text { Sub-Saharan } \\
\text { Africa }\end{array}$ \\
\hline 150 & Serbia & SRB & $\begin{array}{l}\text { Orthodox } \\
\text { East }\end{array}$ & & Orthodox East \\
\hline 151 & Seychelles & SYC & & $\begin{array}{l}\text { Sub-Saharan } \\
\text { Africa }\end{array}$ & $\begin{array}{l}\text { Sub-Saharan } \\
\text { Africa }\end{array}$ \\
\hline 152 & Sierra Leone & SLE & & $\begin{array}{l}\text { Sub-Saharan } \\
\text { Africa }\end{array}$ & $\begin{array}{l}\text { Sub-Saharan } \\
\text { Africa }\end{array}$ \\
\hline 153 & Singapore & SGP & Indic East & & Indic East \\
\hline 154 & Slovakia & SVK & $\begin{array}{l}\text { Returned } \\
\text { West }\end{array}$ & & Returned West \\
\hline 155 & Slovenia & SVN & $\begin{array}{l}\text { Returned } \\
\text { West }\end{array}$ & & Returned West \\
\hline 156 & $\begin{array}{l}\text { Solomon } \\
\text { Islands }\end{array}$ & SLB & & New West & New West \\
\hline 157 & Somalia & SOM & & $\begin{array}{l}\text { Sub-Saharan } \\
\text { Africa }\end{array}$ & $\begin{array}{l}\text { Sub-Saharan } \\
\text { Africa }\end{array}$ \\
\hline 158 & South Africa & ZAF & $\begin{array}{l}\text { Sub-Saharan } \\
\text { Africa }\end{array}$ & & $\begin{array}{l}\text { Sub-Saharan } \\
\text { Africa }\end{array}$ \\
\hline 159 & South Sudan & SSD & & $\begin{array}{l}\text { Sub-Saharan } \\
\text { Africa }\end{array}$ & $\begin{array}{l}\text { Sub-Saharan } \\
\text { Africa }\end{array}$ \\
\hline 160 & Spain & ESP & Old West & & Old West \\
\hline 161 & Sri Lanka & LKA & & Indic East & Indic East \\
\hline 162 & Sudan & SDN & & $\begin{array}{l}\text { Sub-Saharan } \\
\text { Africa }\end{array}$ & $\begin{array}{l}\text { Sub-Saharan } \\
\text { Africa }\end{array}$ \\
\hline 163 & Suriname & SUR & & Latin America & Latin America \\
\hline 164 & Swaziland & SWZ & & $\begin{array}{l}\text { Sub-Saharan } \\
\text { Africa }\end{array}$ & $\begin{array}{l}\text { Sub-Saharan } \\
\text { Africa }\end{array}$ \\
\hline 165 & Sweden & SWE & $\begin{array}{l}\text { Reformed } \\
\text { West }\end{array}$ & & Reformed West \\
\hline
\end{tabular}


Appendix 2: Continued

\begin{tabular}{|c|c|c|c|c|c|}
\hline ID & $\begin{array}{l}\text { Country } \\
\text { Name }\end{array}$ & $\begin{array}{l}\text { Country } \\
\text { Code }\end{array}$ & $\begin{array}{l}\text { Welzel } \\
\text { Category }\end{array}$ & $\begin{array}{l}\text { Extended } \\
\text { Inoguchi/Le } \\
\text { Category }\end{array}$ & $\begin{array}{l}\text { Ten Region } \\
\text { Category }\end{array}$ \\
\hline 166 & Switzerland & $\mathrm{CHE}$ & $\begin{array}{l}\text { Reformed } \\
\text { West }\end{array}$ & & Reformed West \\
\hline 167 & $\begin{array}{c}\text { Syrian Arab } \\
\text { Republic }\end{array}$ & SYR & & Orthodox East & Orthodox East \\
\hline 168 & Tajikistan & TJK & & Orthodox East & Orthodox East \\
\hline 169 & Thailand & THA & Indic East & & Indic East \\
\hline 170 & $\begin{array}{l}\text { The former } \\
\text { Yugoslav } \\
\text { Republic of } \\
\text { Macedonia }\end{array}$ & MKD & $\begin{array}{l}\text { Orthodox } \\
\text { East }\end{array}$ & & Orthodox East \\
\hline 171 & Timor-Leste & TMP & & Indic East & Indic East \\
\hline 172 & Togo & TGO & & $\begin{array}{l}\text { Sub-Saharan } \\
\text { Africa }\end{array}$ & $\begin{array}{l}\text { Sub-Saharan } \\
\text { Africa }\end{array}$ \\
\hline 173 & Tonga & TON & & New West & New West \\
\hline 174 & $\begin{array}{l}\text { Trinidad and } \\
\text { Tobago }\end{array}$ & TTO & & Latin America & Latin America \\
\hline 175 & Tunisia & TUN & & Islamic East & Islamic East \\
\hline 176 & Turkey & TUR & Islamic East & & Islamic East \\
\hline 177 & Turkmenistan & TKM & & Orthodox East & Orthodox East \\
\hline 178 & Tuvalu & TUV & & New West & New West \\
\hline 179 & Uganda & UGA & $\begin{array}{l}\text { Sub-Saharan } \\
\text { Africa }\end{array}$ & & $\begin{array}{l}\text { Sub-Saharan } \\
\text { Africa }\end{array}$ \\
\hline 180 & Ukraine & UKR & $\begin{array}{l}\text { Orthodox } \\
\text { East }\end{array}$ & & Orthodox East \\
\hline 181 & $\begin{array}{c}\text { United Arab } \\
\text { Emirates }\end{array}$ & ARE & & Islamic East & Islamic East \\
\hline 182 & $\begin{array}{l}\text { United } \\
\text { Kingdom }\end{array}$ & GBR & $\begin{array}{l}\text { Reformed } \\
\text { West }\end{array}$ & & Reformed West \\
\hline 183 & $\begin{array}{l}\text { United } \\
\text { Republic of } \\
\text { Tanzania }\end{array}$ & TZA & $\begin{array}{l}\text { Sub-Saharan } \\
\text { Africa }\end{array}$ & & $\begin{array}{l}\text { Sub-Saharan } \\
\text { Africa }\end{array}$ \\
\hline 184 & $\begin{array}{c}\text { United States } \\
\text { of America }\end{array}$ & USA & New West & & New West \\
\hline 185 & Uruguay & URY & Latin America & & Latin America \\
\hline 186 & Uzbekistan & UZB & & Orthodox East & Orthodox East \\
\hline 187 & Vanuatu & VUT & & New West & New West \\
\hline 188 & Venezuela & VEN & Latin America & & Latin America \\
\hline 189 & Viet Nam & VNM & Sinic East & & Sinic East \\
\hline 190 & Yemen & YEM & & Islamic East & Islamic East \\
\hline 191 & Yugoslavia & YUG & & Orthodox East & Orthodox East \\
\hline 192 & Zambia & ZMB & $\begin{array}{l}\text { Sub-Saharan } \\
\text { Africa }\end{array}$ & & $\begin{array}{l}\text { Sub-Saharan } \\
\text { Africa }\end{array}$ \\
\hline 193 & Zimbabwe & ZWE & $\begin{array}{l}\text { Sub-Saharan } \\
\text { Africa }\end{array}$ & & $\begin{array}{l}\text { Sub-Saharan } \\
\text { Africa }\end{array}$ \\
\hline
\end{tabular}

